Revised, 4/1/2019:

\title{
The Belt and Road Initiative: Reshaping Economic Geography in Central Asia?*
}

Julia Bird ${ }^{1}$, Mathilde Lebrand ${ }^{2}$, Anthony J. Venables ${ }^{3}$

\author{
${ }^{1}$ Vivid Economics, \\ ${ }^{2}$ The World Bank, \\ ${ }^{3}$ University of Oxford \& Monash University.
}

\begin{abstract}
:
This paper develops a computable spatial equilibrium model of Central Asia and uses it to analyze the possible effects of the Belt and Road Initiative on the economy of the region. The model captures international and subnational economic units and their connectivity to each other and the rest of the world. Aggregate real income gains from the Belt Road Initiative range from less than 2 percent of regional income if adjustment mechanisms take the form of conventional Armington and monopolistic competition, to around 3 percent if there are localization economies of scale and labor mobility. In the latter case, there are sizeable geographical variations in impact, with some areas developing clusters of economic activity with income increases of as much as 12 percent and a doubling of local populations, while other areas stagnate or even decline.
\end{abstract}

Keywords: regional integration, transport infrastructure, spatial modeling, economic geography, Central Asia.

JEL classification: F12, F15, R11, R13.

* Forthcoming, Journal of Development Economics

This project was supported by the World Bank's Global Solutions Group on Territorial Development under its program on spatial productivity, with financial contributions from UK DFID. Thanks to referees and to participants in the authors' workshop, Washington DC, September 2018, and the Australasian Trade Workshop, Melbourne, March 2019, for helpful comments.

Corresponding author:

A.J. Venables

Dept of Economics

University of Oxford,

Manor road

Oxford OX1 3UQ

UK 


\section{Introduction}

The Belt and Road Initiative (BRI) is a project that seeks to improve connectivity between China and the rest of Asia, the Middle East and on to Africa and Europe. The initiative, launched in 2013, encompasses more than 65 countries representing over 62 percent of the world's population, and has a total cost of more than $\$ 1$ trillion (estimated by some commentators to be close to $\$ 8$ trillion). Central Asia is particularly affected by a series of major infrastructure investments which are strategic transit routes for China, and which will simultaneously improve transport links within this remote region and between it and the rest of the world. This paper explores the possible effect of these investments on the economies of Central Asia by conducting a series of experiments in a spatially disaggregate general equilibrium model of the region and its external trade.

The experiments we consider are based on World Bank estimates from de Soyres et al. (2019). These estimates are of transport times across the region, and how these may be affected by the BRI. Our focus is on changes brought about by improved rail infrastructure, and by a package of further measures to reduce border crossing times. The World Bank estimates indicate that transport savings are large but highly differentiated, affecting different places in different ways. Some places experience little direct effect, for some the effect on intra-regional trade is quite large, and for others the effect is mainly on trade flows outside the region. Depending on initial trade patterns, the transport cost savings may fall relatively more on imports or on exports, hence affecting different sectors and having different implications for price and output responses.

The tools of international economics and economic geography provide ways of analyzing such changes, and our approach is to develop a series of different scenarios, varying principally in the economic adjustment mechanisms that operate. A first, conservative, approach is to assume fixed endowments and technologies throughout the region. Effects of trade shocks on real incomes are then relatively small; the direct cost savings of cheaper transport are only slightly amplified by economic adjustment to the new equilibrium. We add to this mobility of workers within countries and the possibility of landuse change, as land is converted from agricultural to urban use. Finally, we suppose that technology in the manufacturing sector exhibits agglomeration economies, so productivity is an increasing function of the scale of local economic activity. These mechanisms create the possibility that better infrastructure enables centers of economic activity to expand and new centers to develop. Such centers are likely to be well connected urban areas which are on BRI routes, which can draw in labor from other areas, and in which productivity can be enhanced by agglomeration forces. Their expansion and productivity growth will be a major factor in raising income levels in the centers and nationally.

The results we present in these scenarios are illustrative rather than predictive; the model cannot predict with any confidence exactly where a cluster of activity might develop. However if, as evidence suggests, there are agglomeration economies that can raise productivity and competitiveness in a place, then it is possible that a change in transport costs can have a catalytic effect. ${ }^{1}$ Whether - and where such effects will occur depend on numerous aspects of the economic environment and economic policy. Policy makers should be aware of these possibilities, and the paper is innovative in so far as it shows how this could play out in response to particular changes in connectivity, such as those that may be brought about by the BRI. An important contribution of the paper is to explore the implications of

\footnotetext{
1 For a survey of evidence on agglomeration economies see Combes and Gobillon (2015). For analytical work see e.g. Allen and Arkolakis (2019), Redding (2016), Fujita et al, (1999).
} 
such effects for results delivered by the model, and thereby inform both policy and future modeling work in trade and spatial economics.

In order to capture this wide range of adjustment mechanisms the model has a number of key features. First, the model is both international and sub-national. Internationally, it covers 7 countries in or close to Central Asia and 4 'access points' through which they trade with the rest of the world. Subnationally, it contains provinces and some distinct cities, giving a total of 52 geographical units (henceforth referred to as cells). The international dimension allows us to consider changes in links to the outside world, and also the interactions between a set of neighboring countries; effects in one will not be independent of effects in others. The sub-national dimension is important because many of the countries affected are large, and transport improvements only occur in particular areas. Stimulus to economic activity may be spatially concentrated so its effects - in aggregate and on regional inequalities - need to be modeled at quite a fine level of geographical detail.

Second, the model pays attention to the mobility of labor and the possibility of land-use change that enables cities to grow. Our starting case assumes that labor is immobile, tied to its initial cell and country. We then relax this, allowing labor to move between cells within countries but not internationally in response to changes in real wages. This source of economic flexibility generally magnifies the impact of the BRI on particular cells and enables the growth of regional specialization. The largest benefits are derived (for some places, if not all) when labor is relatively mobile and when cities and other manufacturing sectors are enabled to grow without driving urban rents up too sharply.

Third, the model distinguishes between three sectors of activity in each economic geographical cell. Two of these sectors have limited spatial mobility. The primary sector (accounting for around 25\% of employment in the region) may have quite an elastic supply response, but is spatially anchored because of its dependence on land and natural resource inputs. Non-tradable services (accounting for around $39 \%$ of employment) are relatively immobile because they serve local demand. The third sector is a composite of manufacturing and tradable services, a sector that is relatively mobile, vulnerable to import competition, and with a potential to expand to serve export markets.

Fourth, we devote considerable attention to the implications of different supply responses by this composite manufacturing sector. A conservative case is captured by the 'Armington' assumption, where the number of 'varieties' (or firms) produced in each cell is held constant, constraining the supply response. We compare this with two other cases. Monopolistic competition permits entry and exit of firms (and varieties) in response to changes; this captures relatively 'footloose' activities and, since there are input-output linkages in the model, creates some (weak) incentives for cluster formation. Finally, we add localization economies in the manufacturing sector, i.e. external economies of scale that are sector and location specific. ${ }^{2}$ This captures the idea that some places may be able to gain productivity advantage by developing clusters of activity, particularly when combined with intracountry labor mobility.

The main conclusions we derive from the modeling are as follows. First, with limited supply response (monopolistic competition) the full economic gains amount to a $1.9 \%$ increase in average real income per capita in the region; this is about one third larger than the direct transport cost savings created by building the BRI infrastructure. It is associated with an increase in the value of trade within the region and between the region and the rest of the world, rising from $38 \%$ of GDP to $43 \%$ of GDP. Some cells

\footnotetext{
2 'Localization economies' is the term given to agglomeration economies which are both location and sector specific, and are also sometimes referred to as Marshallian economies.
} 
and countries expand manufacturing production relative to the primary sector, and others do the reverse; the former is more likely for places with a relatively high initial share of employment in manufacturing, and for which the connectivity improvements brought about by the BRI are mainly on export routes and are intra-regional, rather than links to the rest of the world.

With a more elastic supply response - including labor mobility and localization economies - the aggregate gains are likely to be much larger, rising to $2.7 \%$ of initial GDP, nearly double the direct cost savings. In these cases the effects are spatially uneven, with different cells in a country having widely different outcomes. In the absence of localization economies, labor mobility tends to equalize differences in GDP per capita; workers move to regions with more positive outcomes, increasing their labor supply and reducing relative wages. However, the presence of localization economies generally reverses this; as workers move into a cell so scale effects tend to raise productivity, creating a virtuous circle of growth. ${ }^{3}$ There are then large changes in economic geography, with some places experiencing large-scale manufacturing growth, per capita income increases of around 12\%, and a doubling of local population. Such population increases seem large until they are set against historical change in rapidly developing economies. While the gains from the BRI are greatest in this last case, it is difficult to predict which places will develop these clusters, so the results should be regarded as indicative of possibilities, rather than predictive of actual change.

This paper supplements other recent work written on the BRI. Lall and Lebrand (2019) provide analysis of the spatially differentiated effects of the initiative, using similar data. They build a series of single country models, based on work by Fajgelbaum and Redding (2014) on Argentina, in which they investigate intra-country effects of the BRI. They find that gains are concentrated in locations near to border points, and in urban centers and that higher levels of labor mobility help lower any potential impacts on spatial inequalities. De Soyres et al. (2020) construct a global model, building on work of Caliendo and Parro (2015). Our paper complements these papers by combining subnational and international effects and, most critically, providing a richer modeling of the supply side response of the economy to shocks.

The paper builds on work in several areas of economic literature. First, the model developed is essentially a quantitative economic geography model, with the location of population and economic activity endogenously determined across the economic space by the geography and underlying parameters and model structure. This field has rapidly grown in recent years, and reviews of this literature and the types of analysis that can be performed are laid out in Redding and Rossi-Hansberg (2017) and Redding and Turner (2015). Many papers in this field look at the distribution of a single aggregate economic activity across space; the model of the present paper distinguishes three sectors of production, so capturing traditional comparative advantage as well as economic geography forces. Second, the paper builds on work related to the impact of infrastructure on both trade and regional growth, including Donaldson (2018), Duranton et al. (2014) and Allen and Arkolakis (2019); our quantification is ex ante, based on calibration, rather than estimation based on a historical experiment. Third, the impact of the BRI is modeled through a reduction in travel costs between pairs of cells both within and across national borders; we combine both internal trade and cross-country trade in a same setting. This builds on work that looks at how high transport times act as barriers to trade, and the relationship between travel times and trade costs including Djankov et al. (2010), Hummels and Schaur (2013), and Roberts et al. (2012). Finally, the paper also highlights the importance of internal migration,

\footnotetext{
${ }^{3}$ We assume that labor mobility is less than perfect, so this reversal is consistent with stability of equilibrium, see section 4.3 .
} 
building on other work on within-country factor mobility and trade, including Redding (2016). This, mobility, together with localization economies, creates the significant productivity increases, cluster growth, and heterogeneous spatial outcomes that we find.

The paper continues as follows. In section 2, we outline the main BRI projects in Central Asia, their impact on the transport network, and our representation of the geography of the region. Section 3 outlines the model, and in section 4 we discuss the data and model calibration. Section 5 presents our central results concerning the effects of BRI on the transport network, and Section 6 extends the BRI experiment to include reductions in border delays. Section 7 concludes.

\section{The BRI in Central Asia}

The BRI affects Central Asia principally through three corridors; the new Eurasian Land Bridge (a Northern route, from Urumqi in China to Astana and Moscow); the China Central-Asia West-Asia corridor (Urumqi to Almaty, Tashkent, dividing to Aktau and to Ashgabat, Tehran, Ankara); and the China Pakistan corridor (Urumqi, Almaty, Islamabad, Gwadar). Figure 1 marks these places and indicates the infrastructure improvements on these corridors and the related links that are planned or undertaken. Many of these investments are designed principally as transit routes for trade between China and the West, with construction financed largely by loans (sometimes concessionary) to governments in 'BRI participating economies' (including the six in this study). ${ }^{4}$ Our concern in this paper is with the consequent improvements in connectivity both within the region and between the region and the rest of the world, and the impact of these improvements on countries through which these corridors pass.

Our model representation of this is 52 geographical cells, covering the whole of 6 countries (Kazakhstan, Kyrgyzstan, Pakistan, Tajikistan, Turkmenistan, Uzbekistan) and including 3 western provinces of China (which we will refer to as China-3). Some of the cells are quite large provinces and others are specific cities. In addition to these cells, the model contains 4 'access points' through which the region trades with the rest of the world, namely Chongqing, Gwadar (in Pakistan), Istanbul and Moscow. The cells and access points are illustrated on Figure 2, and are listed in Appendix 1.

Analysis of the possible effects of the BRI requires estimates of connectivity between these cells, and of the likely changes in connectivity brought about by BRI investments. Our source for this is the detailed study undertaken by de Soyres et al. (2019) who use a combination of geographical data and network algorithms to calculate shipping times between points covering 1,818 cities in 71 countries. They combine this with detailed data on BRI infrastructure projects to estimate changes in these journey times. We connect the main urban area in each cell of our study to the nearest city in their database to produce matrices of before and after BRI shipping times.

\footnotetext{
${ }^{4}$ For an overview of the BRI see chapter 2 of OECD (2018). We ignore construction and financing issues.
} 
Figure 1: Map of Central Asian Transport Improvements under the BRI.

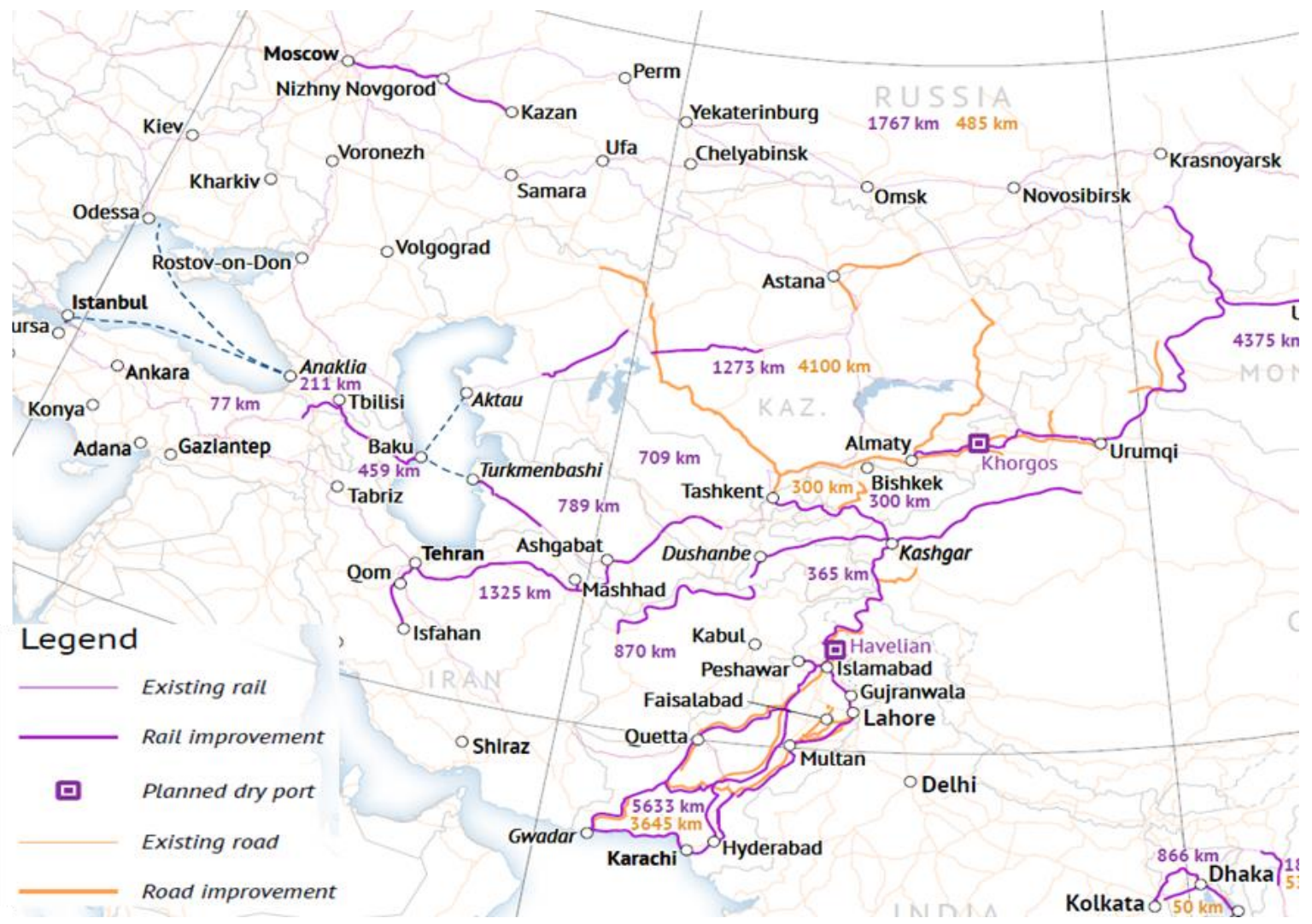

Source: Reed and Trubetskoy (2019).

Figure 2: Map of countries, cells, and access points

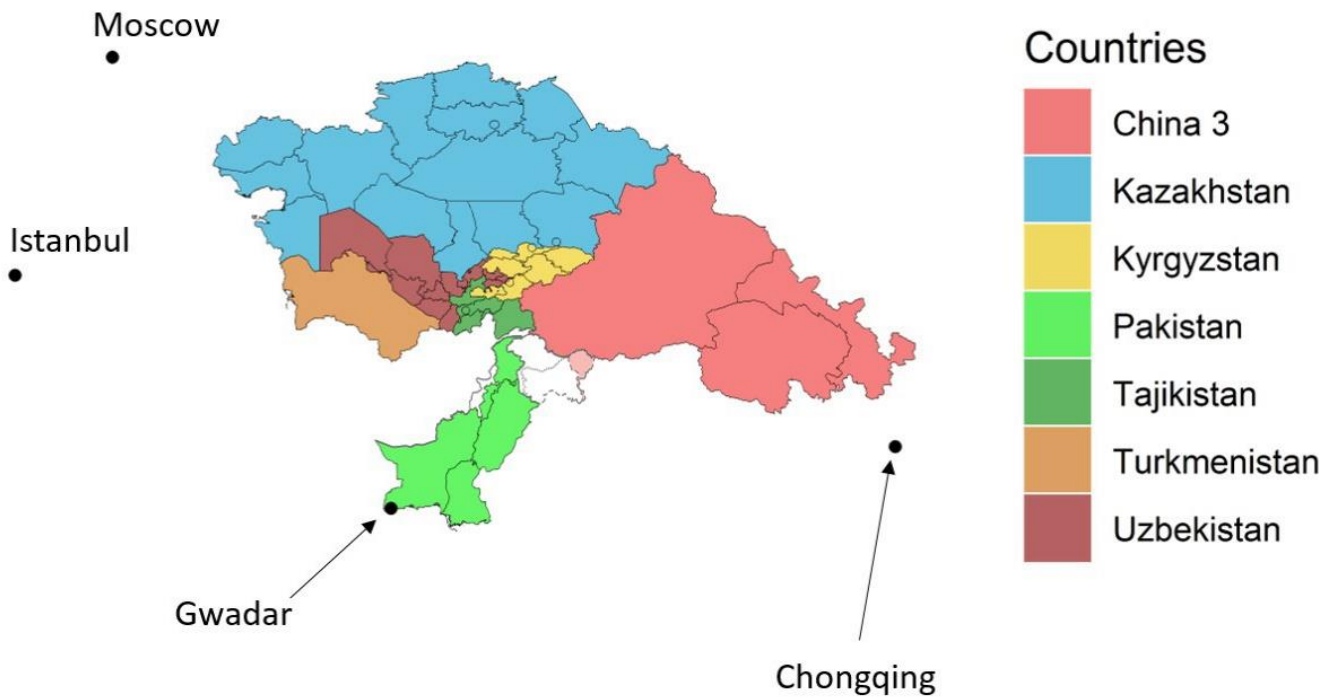


To use this transport time data in the model we have to convert it to an ad valorem iceberg measure. We denote the transport cost factor for shipping sector $s$ output from cell $i$ to cell $j$ as $\tau_{i j}^{S}$. We map transport times into transport cost factors according to $\tau_{i j}^{S}=1+\lambda^{S}$ time ${ }_{i j}{ }^{\theta}$ with $\theta=0.75$, so costs increasing less than proportionately with time. This functional form and parameter value are in line with similar assumptions elsewhere in the literature on transport in Asia, as in Alder (2019), BaumSnow et al. (2018) and Roberts et al. $(2010,2012)$. Time is measured in days, and the parameter $\lambda^{s}$ varies by sector, highest for non-tradable services $\left(\lambda^{s}=1.8\right)$ which are produced and sold predominantly in the same cell, lowest for manufacturing $\left(\lambda^{S}=0.09\right)$, and primary goods lying between the two $\left(\lambda^{s}=0.18\right)$. These parameter values imply, for example, that prior to the BRI the shipment of goods between Urumqi in China and Almaty in Kazakhstan takes nearly 8 days, including border times, which is equivalent to an iceberg transport cost factor of 1.42 for manufacturing and 1.84 for primary goods. Shipment between Almaty and Astana, both in Kazakhstan, takes 1.1 days, equivalent to an iceberg transport cost factor of 1.09 for manufacturing and 1.19 for primary goods.

Turning to the changes, table 1 gives an indication of the magnitude of the estimated reductions in journey time to be brought about by the BRI. This aggregates the cell-to-cell data we use in the model into country-to-country measures (unweighted averages of the reduction in transport times between each pair of cells in the respective countries); reductions in transport times to the four access points with the rest of the world are reported below the line. The reductions are clearly highly variable and in many cases large.

Table 1: Reduction in Transport Time, country-to-country averages

\begin{tabular}{lccccccc}
\hline & China-3 & Kazakhstan & Kyrgyzstan & Pakistan & Tajikistan & Turkmenistan & Uzbekistan \\
\hline China-3 & $0 \%$ & $13 \%$ & $46 \%$ & $40 \%$ & $0 \%$ & $0 \%$ & $8 \%$ \\
Kazakhstan & $13 \%$ & $17 \%$ & $1 \%$ & $0 \%$ & $46 \%$ & $63 \%$ & $28 \%$ \\
Kyrgyzstan & $46 \%$ & $1 \%$ & $0 \%$ & $0 \%$ & $33 \%$ & $41 \%$ & $37 \%$ \\
Pakistan & $40 \%$ & $0 \%$ & $0 \%$ & $32 \%$ & $6 \%$ & $7 \%$ & $5 \%$ \\
Tajikistan & $0 \%$ & $46 \%$ & $33 \%$ & $6 \%$ & $0 \%$ & $4 \%$ & $7 \%$ \\
Turkmenistan & $0 \%$ & $63 \%$ & $41 \%$ & $7 \%$ & $4 \%$ & $0 \%$ & $13 \%$ \\
Uzbekistan & $8 \%$ & $28 \%$ & $37 \%$ & $5 \%$ & $7 \%$ & $13 \%$ & $1 \%$ \\
\hline Chongqing & $0 \%$ & $11 \%$ & $41 \%$ & $8 \%$ & $0 \%$ & $0 \%$ & $8 \%$ \\
Gwadar & $42 \%$ & $0 \%$ & $1 \%$ & $28 \%$ & $10 \%$ & $11 \%$ & $8 \%$ \\
Istanbul & $21 \%$ & $15 \%$ & $11 \%$ & $10 \%$ & $0 \%$ & $0 \%$ & $19 \%$ \\
Moscow & $12 \%$ & $2 \%$ & $0 \%$ & $14 \%$ & $0 \%$ & $0 \%$ & $15 \%$ \\
\hline Notes
\end{tabular}

Notes: China-3 is provinces (main cities) of Gansu (Lanzhou), Qinghai (Xining) and Xingjiang (Urumqi).

\section{The model}

The 52 geographical cells at the core of the study are modeled in detail, while the 4 access points are represented just as supply and demand functions for trade with rest of the world, i.e. imports can be bought at fixed world prices, and exports can be sold according to a highly elastic rest of world demand curve. Within each cell there are households that consume goods and services and supply labor, and 
firms, divided into three sectors, and producing goods and services for local, regional, and international markets.

\section{Households}

We assume a single type of labor, not distinguishing by skill level. The population of each cell is, $L_{i}$, where cells are indexed by $i=1 \ldots 52$, with population scaled to match the size of the labor force in each city. Every household is assumed to consist of a representative individual who works in their cell of residence and supplies a fixed amount of labor. In our base experiments labor is assumed to be immobile; in some scenarios we relax this to allow partial labor mobility within each country (but not between countries) in response to changes in real wages (utility) across cells in a country.

Household income comes principally from the wage $w_{i}$ in the cell in which the household lives and works. Households also receive a lump sum transfer $m_{i}$ as land rents (and profits, if any) are distributed; we assume that each household in a country receives an equal share of the total rents and profits earned in that country. Given their income, utility maximizing households demand composite goods from the three sectors, $s=1 \ldots 3$, according to Cobb-Douglas preferences. The price (or price index) of the sector $s$ composite good in cell $i$ is $P_{s i}$, and utility is income deflated by the price index so household utility in cell $i$ is,

$$
u_{i}=\left(w_{i}+m_{i}\right) /\left(P_{1 i}^{\beta_{1}} P_{2 i}{ }^{\beta_{2}} P_{3 i}^{\beta_{3}}\right), \text { with expenditure shares } \sum_{s} \beta_{s}=1 .
$$

The sector s price index in cell $i$ is a function of the prices, $\mathrm{p}_{s \mathrm{j}}$, and numbers of varieties, $\mathrm{n}_{s \mathrm{j}}$, that are shipped from cell $j$ to cell $i$. It is CES and takes the form,

$$
P_{s i}=\left[\sum_{j} A_{j i}^{S} n_{s j}\left(p_{s j} \tau_{j i}^{S}\right)^{1-\sigma_{s}}\right]^{1 /\left(1-\sigma_{s}\right)} .
$$

Shipping incurs iceberg transport costs $\tau_{j i}^{S}$, and we also allow origin and destination preference differences, given by parameter $A_{j i}^{S}$. From these preferences we derive the demand function of households in cell $i$ for a single sector $s$ variety produced in $j$; this is denoted $x_{s j i}^{H}$ (where superscript $H$ indicates household) and takes the form

$$
x_{s j i}^{H}=p_{s j}{ }^{-\sigma_{s}} A_{j i}^{S} \tau_{j i}^{s 1-\sigma_{s}} e_{s i}^{H} P_{s i}^{\sigma_{s}-1}, \quad e_{s i}^{H}=\mathrm{L}_{s i} \beta_{s}\left(w_{i}+m_{i}\right) .
$$

The price elasticity of demand (and elasticity of substitution between varieties) in sector $\mathrm{s}$ is the parameter $\sigma_{s}$.

\section{Production}

The three sectors of economic activity are: primary (agriculture and mining): manufacturing and tradable services: non-tradable goods and services, including housing and retail. The sectors differ in technology, demand, and tradability. We outline their technology and demand in general terms, then turn to sector specific detail.

The unit costs of sector $s$ in cell $i$ are a Cobb-Douglas function of input prices,

$$
c_{s i}=w_{i}^{\alpha_{w s}} r_{i}^{\alpha_{r s}} P_{1 i}^{\alpha_{1 s}} P_{2 i}^{\alpha_{2 s}} P_{3 i}^{\alpha_{3 s}} / z_{s i}
$$


Inputs are labor with wage $w_{i}$, land with price $r_{i}$, and intermediate goods with price indices $P_{s i}$. These price indices are assumed to take the same form as those faced by households (eqn. 2). ${ }^{5}$ Exponents (input shares) sum to unity, so input-output coefficients for inputs of each sector per unit output (in value terms) of sector s are the exponents $\alpha_{1 s}, \alpha_{2 s}, \alpha_{3 s}$. The final term, $z_{s i}$, is a sector and cell specific productivity parameter that we discuss further below.

The total level of sales made by a sector $s$ firm in cell $i$ is denoted $x_{s i}$, and the total value of sales by all such firms is $p_{s i} n_{s i} x_{s i}$. Cost minimization yields input demands:

Labor demand by sector $s$ in cell $i$ :

$$
\begin{aligned}
& L_{s i}=\alpha_{w s} p_{s i} n_{s i} x_{s i} / w_{i} \\
& K_{s i}=\alpha_{r s} p_{s i} n_{s i} x_{s i} / r_{i} \\
& e_{s i}^{t}=\alpha_{t s} p_{s i} n_{s i} x_{s i} / P_{t i}
\end{aligned}
$$

Intermediate demand by sector $s$ in cell $i$ for sector $t$ :

Firm's sales equal demand from household and other firms in all cells $j$, given by

$$
x_{s i}=\sum_{j} p_{s i}{ }^{-\sigma_{s}} A_{i j}^{S} \tau^{s}{ }_{i j}{ }^{1-\sigma_{s}} E_{s j} P_{s j}{ }^{\sigma_{s}-1}, \text { where } E_{s j}=e_{s j}^{H}+e_{s j}^{1}+e_{s j}^{2}+e_{s j}^{3} .
$$

This is the demand function, (3), summed across all cells, and including not just household demands but also expenditure on intermediate demands, $e_{s i}^{t}, s, t=1,2,3$. We now discuss each sector in turn.

Primary sector, $s=1$ : Production uses labor, rural land, and intermediates (composites of goods from each sector entering through an input-output structure) and each cell produces a single 'variety', differentiated only by the cell where it is produced (so for $s=1, n_{s i}=1$ ). There is perfect competition, so price equals unit cost, $p_{s i}=c_{s i}$. Two sorts of parameters describe the sector. One is the factor shares, input-output relationships, demand elasticities and trade cost parameters, and these are listed in appendix 4 . The other is the cell-specific productivity parameters, $z_{s i}$; these parameters are derived from calibration, such that employment and output levels for each cell match the data.

Manufacturing, $s=2$ : Production is undertaken by distinct firms, each with its own variety (so for $s$ $=2, n_{s i} \geq 0$ ), and following the standard CES modeling of product differentiation. As in the primary sector, technology and demand parameters are listed in appendix 4 and cell specific productivities are derived from calibration.

Our simulations explore the implications of different responses by manufacturing firms. The simplest case is that the number of firms in each cell is held constant, and shocks cause a response in the scale of operation of each firm. This is the Armington case where there is perfect competition, no entry, exit, or relocation of firms/ varieties, and $n_{2 i}=1$. A second case is monopolistic competition, where the number of firms in each cell changes in response to profit/ loss opportunities. In the standard manner of Dixit-Stiglitz firms are assumed to have a fixed cost and set price a constant mark-up above unit cost. Equilibrium profits are zero and this is achieved when sales are equal to a target level that can be normalized at unity, i.e. $x_{2 i}=1 .^{6}$ The number of firms $n_{2 i}$ is now endogenous, while the sales of each, $x_{2 i}$, is fixed; this generates larger quantity responses than the Armington case.

The third case includes localization economies, so the productivity of firms is increasing in the number of firms active in the same cell-sector. This takes the form $z_{2 i}=\bar{z}_{2 i}\left(1+\alpha\left(n_{2 i} / \bar{L}_{i}\right)\right)^{\rho}$. The base productivity, $z_{2 i}$, is calibrated on the data. The right-hand side of the equation splits this into two parts, $\bar{z}_{2 i}$ (held constant in simulation) and an additional component which represents increasing returns as a

\footnotetext{
${ }^{5}$ This means that the sectoral composites consumed by households are the same as those used as intermediate goods.

6 For details see for example section 3 of Redding and Rossi-Hansburg (2017).
} 
function of the density of firms in the sector-cell, i.e. the number of firms divided by initial population $n_{2 i} / \bar{L}_{i}{ }^{7} \quad$ If, following the transport investment, the number of firms changes then localization economies generate changes in productivity, where $\alpha, \rho>0$ if there are increasing returns.

Non-traded goods and services, $\boldsymbol{s}=3$ : This sector is monopolistically competitive, and parameters set such that trade flows are very low. It follows that the scale of the sector is set principally by local demands, and that radical shifts in the location of production are not possible.

\section{Trade}

Goods and services move within and across countries. Within each country, trade flows are determined by the relative demand and supply of goods in each cell together with iceberg trade cost factors $\tau_{i j}^{S}$ from the network data. Between countries we observe bilateral trade data. We calibrate the model to this data by assuming that, in addition to network trade costs $\tau_{i j}^{S}$, there are country origin-destination shift parameters, $A_{i j}^{S}$, which are sector specific and capture national preferences for goods from other countries. For origins and destinations $i, j$ both in the same country these take value unity. Between countries they may differ from unity but take a common value, $A_{i j}^{S}$, for trade between all origin cells $i$ in one country and destination cells $j$ all in another.

The initial international trade flows are defined by the data, in which national trade balances are nonzero. We assume that net imports are paid for by remittances from migrants or other capital flows; the base levels of remittances/ capital flows do not change with the experiments, and neither therefore do national trade balances.

\section{Labor mobility and factor supply}

Each of the 52 cells has initial endowments of labor $\bar{L}_{i}$, and of urban and rural land, $\bar{K}_{U i}$ and $\bar{K}_{R i}$. In some of our experiments we hold the labor force of each cell constant, while in others we allow for varying degrees of labor mobility between cells within each country. Labor mobility is captured by assuming that, for cells $i$ and $j$ in the same country, $i, j \in C, L_{i}=\bar{L}_{i} \hat{u}_{i}{ }^{\mu} /\left(\sum_{j \in C} L_{j} \hat{u}_{j}{ }^{\mu} / \sum_{j \in C} L_{j}\right)$, where $\bar{L}_{i}$ is the base exogenous population in the cell, and $\hat{u}_{i}$ is the proportionate change in utility in cell $i$ associated with some experiment. The parameter $\mu$ captures the sensitivity of location decisions to intra-country variations in utility. ${ }^{8} \mu=0$ implies that labor is completely immobile within the country, and $\mu=\infty$ gives perfect labor mobility such that base-level utility differentials are maintained. The total national population must equal the sum of all cell populations within the country, $\bar{L}_{c}=\sum_{i \in c} L_{i}$.

We have separate endowments of rural and urban land, respectively $\bar{K}_{R i}, \bar{K}_{U i}$, the former used in sector 1 and the latter in sectors 2 and 3. In some of the scenarios the amount of urban land is able to adjust in response to changes in the urban-rural rent differential, so that $K_{U i}=\bar{K}_{U i}\left(\hat{r}_{U i} / \hat{r}_{R i}\right)^{v}$, where $\hat{r}_{U i}, \hat{r}_{R i}$ are respectively the proportionate changes in the rental of urban and rural land. Essentially, this captures the idea that urban expansion encounters increasing urban land rents relative to rural. ${ }^{9}$ We hold the

\footnotetext{
7 Cells have widely differing area, population and output levels. Density is therefore the appropriate measure, since it goes some way towards controlling for these differences.

8 This functional form for the dependence of population on utility can be derived by giving individuals idiosyncratic preferences over cells and integrating over the population, see for example section 4 of Redding and Rossi-Hansburg (2017).

9 This can be thought of as a reduced form of an Alonso-Mills-Muth urban model, in which larger cities involve commuting costs this creating a premium on land rents.
} 
quantity of rural land constant, justified by the fact that in each country the area of rural land is several orders of magnitude greater than the urban area.

\section{Equilibrium}

Given the transport network, endowments of labor and land, and parameters of the model (including productivity parameters $z_{s i}$ and country origin-destination shift parameters $A_{i j}^{S}$ ), the model generates, in each cell, prices for all goods, wages, and land rents such that markets clear. The calibration sets values of productivity parameters $z_{s i}$ and country origin-destination shift parameters $A_{i j}^{S}$ such that equilibrium employment in each sector and cell matches the employment data, per capita incomes match country level income data, and international trade flows match the trade data.

In our experiments the calibrated model is 'shocked' with new transport times in the trade network, and firms and households adjust their decisions in response to the new geography of the region. We explore different degrees of response under combinations of five different assumptions which are, in summary:

(1) Direct effect: To quantify the scale of the shock we calculate transport cost savings at unchanged base level prices and quantities, i.e. take the transport cost reduction times the base value of exports from each cell to all other cells. ${ }^{10}$ This allows us to observe the direct savings at the region wide level. Between each pair of cells, we take a mean of the reduction in costs of exports and imports as a simple measure of the extent to which a cell is directly affected by the change in transport costs.

(2) Armington supply response: Consumers and producers adjust behavior, but the number of varieties (firms) in each sector and cell is held constant.

(3) Monopolistic competition in manufacturing and non-tradable services sectors: Firms enter and exit in response to profit opportunities, so that equilibrium profits are zero. As usual in a DixitStiglitz setting, this means that equilibrium firm size is constant.

(4) Labor mobility: While the total population of each country remains constant, households move between cells in response to changes in relative real per capita income across cells. We compare zero mobility with a high (but not 'perfect') level of mobility. Population movement has a significant effect on urban land rents, so we also allow land to convert from rural to urban in response to changes in relative urban-rural rents.

(5) Localization economies: Calibration gives sector-cell specific productivity parameters $z_{s i}$. As described above, these are split into two multiplicative elements, the initial calibrated productivity parameter, and a part depending on the ratio of the number of firms in the cell to the base population in the cell. An increase in this ratio raises productivity.

\section{Data, parameters and calibration}

Our data is for the seven countries indicated in Figure 1, and the full listing of countries and cells is given in appendix 1 . The model is calibrated to data on employment, population, land area, national accounts and trade and also uses the network of transport times and their projected changes discussed in section 2. Details of data sources are given in appendix 3.

${ }^{10}$ This is an 'out of equilibrium' calculation, designed purely to quantify the size of the initial shock. 
The calibration proceeds in three main steps. First, we calibrate relative productivity levels across cells in each country, $z_{s i}$, so that equilibrium employment in each sector and cell matches the employment data. Second, the absolute levels of $z_{s i}$ in each country are scaled to match income per capita at a country level. Finally, we calibrate preference parameters $A_{i j}^{S}$ such that the share of country $i$ output being sold in country $j$ is consistent with international trade data. Values of other parameters used in the model are given in appendix 4, and here we discuss those relating to the potential economies of scale and clustering effects.

Localization economies are captured by relationship $z_{2 i}=\bar{z}_{2 i}\left(1+\alpha\left(n_{2 i} / \bar{L}_{i}\right)\right)^{\rho}$. Parameters $\alpha$ and $\rho$ are chosen such that areas with average firm density are $20 \%$ more productive than comparable areas with no firms, and that the cell will the mean value $n_{s i} / \bar{L}_{i}$ has an elasticity of productivity with respect to the number of firms equal to 0.08 , these two restrictions implying parameter values $\alpha=6.67$ and $\rho=0.093$. This translates into a point elasticity of productivity with respect to the number of firms that ranges from 0 in cells with no initial manufacturing to a maximum of $0.088 .{ }^{11}$

Labor is assumed immobile in our initial experiments, and mobility is then set a high, but not perfect level, with elasticity with respect to variation in utility differential of $\mu=10$. Similarly, where urban land expansion is possible, we set a high elasticity with respect to rent differentials of $v=5$, capturing the idea that cities in the region do not face severe land constraints. Importantly, these values are consistent with stability of equilibrium. ${ }^{12}$

In what follows we will interpret simulation results in light of cell-level patterns of economic structure and trade. It is helpful to set the stage for this by reviewing some aspects of the national level data. Table 2 gives total populations and GDP for each country. There is large variation between the countries in the region, with per capita GDP nearly 10 times as large in Kazakhstan as it is in Tajikistan. Table 3 gives the sectoral structure of production. There are wide differences, with China-3 and Kazakhstan having the highest share of employment in manufacturing, and Turkmenistan, Pakistan and Tajikistan the highest shares in primary sectors. On the trade side (Table 4), all countries except China-3 are net importers of manufactures and all, except China-3 and Pakistan, are net exporters of primary products. As noted above, there are large imbalances in goods trade.

11 The elasticity is variable, because of the functional form employed. Much of the empirical literature uses an iso-elastic form to estimate this relationship, but this is inappropriate for application in simulation. It means that if $n_{2 i}=0$ then productivity equals zero, so the cell can never attract a firm. Magnitudes of parameters are chosen to be in line with the literature. Rosenthal and Strange (2004) suggest a consensus range of elasticities of agglomeration between 3\% and 8\%, (see also Combes and Gobillon 2015 and a detailed meta-analysis by Melo et al. 2009). We take values at the upper end of this range because we are only considering localisation effects in manufacturing, and because recent work suggests that the elasticity is somewhat higher in lower and middle income countries than in developed countries (Glaeser and Xiong 2017).

12 The equilibrium is stable. To understand this, think of two relationships on relative real wage ( $\omega$, vertical axis) and relative population ( $\lambda$, horizontal axis) space. The migration relationship is upward sloping, as a higher $\omega$ draws in population. With non-increasing returns the wage relationship is downward sloping, as more labor (higher $\lambda$ ) encounters diminishing returns. Localization economies and increasing returns to scale mean that the wage relationship becomes upward sloping, but the equilibrium remains stable if it is less steep than the migration relationship. This is the case described; a shift in the wage relationship (due to the BRI shock) now gets amplified by labor mobility. If the direction of intersection of the relationships was reversed (as would be the case with perfect labor mobility giving a horizontal migration relationship) then the equilibrium would be unstable. 
Table 2: GDP and Population of sample countries.

GDP (Billion USD) GDP per capita (USD) Population (Millions)

$\begin{array}{lccc}\text { China-3 } & 280.5 & 5066 & 55.4 \\ \text { Kazakhstan } & 135.0 & 7585 & 17.8 \\ \text { Kyrgyzstan } & 6.6 & 1101 & 6.0 \\ \text { Pakistan } & 282.5 & 1580 & 178.8 \\ \text { Tajikistan } & 7.0 & 796 & 8.7 \\ \text { Turkmenistan } & 36.2 & 6712 & 5.4 \\ \text { Uzbekistan } & 67.8 & 2128 & 31.9\end{array}$

Table 3: Sectoral shares of GDP (percent)

\begin{tabular}{lcccc} 
& Primary & Manufacturing & $\begin{array}{c}\text { Manufacturing/ } \\
\text { Manuf + Primary }\end{array}$ & Non-tradables \\
\hline China-3 & 14.7 & 40.7 & 0.73 & 44.7 \\
Kazakhstan & 20.5 & 34.7 & 0.63 & 44.8 \\
Kyrgyzstan & 17.3 & 19.0 & 0.52 & 63.7 \\
Pakistan & 29.5 & 24.9 & 0.46 & 45.6 \\
Tajikistan & 29.4 & 23.3 & 0.44 & 47.3 \\
Turkmenistan & 37.0 & 28.0 & 0.43 & 35.0 \\
Uzbekistan & 21.8 & 33.2 & 0.60 & 45.0
\end{tabular}

Table 4: Exports and Imports relative to GDP (percent)

\begin{tabular}{lcccc} 
Primary & $\begin{array}{c}\text { Manufacturing } \\
\text { exports }\end{array}$ & $\begin{array}{c}\text { Primary } \\
\text { imports }\end{array}$ & $\begin{array}{c}\text { Manufacturing } \\
\text { imports }\end{array}$ \\
\hline China-3 & 0 & 34 & 5 & 14 \\
Kazakhstan & 14 & 11 & 2 & 19 \\
Kyrgyzstan & 5 & 12 & 3 & 77 \\
Pakistan & 1 & 8 & 3 & 14 \\
Tajikistan & 5 & 7 & 4 & 48 \\
Turkmenistan & 17 & 2 & 0 & 13 \\
Uzbekistan & 2 & 9 & 1 & 13
\end{tabular}

\section{The BRI: Building infrastructure}

Our main experiment considers the effects of building the BRI infrastructure and thereby reducing travel times within the region and with the rest of the world. The changes in journey times and hence in transport costs were discussed in section 2, and we now feed these into the model under a variety of different assumptions about supply side responses. First, in section 5.1 we compare direct effects with outcomes under the Armington assumption, and under monopolistic competition with and without labor mobility. Then, in section 5.2 we add localization economies, combining it with monopolistic 
competition and labor mobility, in order to explore the implications of the BRI on the economic geography of the region, and the gains that might come from radical change.

\subsection{BRI and real incomes:}

Although some of the trade cost reductions reported in Table 1 are large, they are applied to sometimes small volumes of initial trade. The direct costs savings - the value of the reduction in transport costs times the initial levels of trade, assuming no economic adjustment -- amount to a real income gain of $1.4 \%$ for the region as a whole. ${ }^{13}$

Table 5 gives average real income gains of each country that follow from this reduction in transport times and subsequent economic responses. The first column (Armington) is a conservative benchmark case. In aggregate, the gains are only marginally greater than the direct effect, but there are noteworthy cross-country differences. Real income growth is particularly large for Kyrgyzstan, which faces a large fall in transport costs while being a net importer of manufacturing. This has two main consequences. First, the cost of Kyrgyzstan's imports falls substantially, leading to lower prices of imports and hence real income growth. Second, there is significant structural change. To understand this, it is helpful to look at the changes in sectoral production given in Table 6. Kyrgyzstan experiences a relatively large expansion in primary output and corresponding contraction of manufacturing production which faces import competition. This is in line with comparative advantage (as indicated by the production shares reported in Table 3) and hence contributes to the gain.

The effect is smallest for Turkmenistan and Uzbekistan, which also see growth in the primary sector, however with a far smaller reduction in the cost of their imports. Prices remain relatively static, and real income growth is small. China-3, Kazakhstan and Pakistan all experience growth in manufacturing, following reductions in their costs of exporting.

In the second column of Table 5, monopolistic competition allows manufacturing firms to enter, exit, and relocate in response to changes in their profitability. At the aggregate level this increases the real income gain to $1.9 \%$, more than a third greater than the Armington effect. At the national level, the additional gain accrues principally to China-3, Kazakhstan, and Pakistan. These are all countries with a relatively large manufacturing base and, as is apparent from Table 6, they are countries that experience expansion of manufacturing output relative to primary (such countries flagged $\mathrm{M}$ in the tables). By contrast, Kyrgyzstan, Tajikistan and Turkmenistan experience contraction of manufacturing, and real income gains that are smaller in this monopolistic competition case than under the Armington assumption. Now the growth of manufacturing in other countries within the region has increased import competition, hurting the manufacturing sectors within these countries, which further specialize in primary good production.

13 In some following figures we will rank cells according to a measure of this direct effect. However, the direct effect has no real income interpretation at the country or cell level because we do not know (without using the model) the division of the cost saving between countries, i.e. the incidence of the cost reduction. In aggregate, for the region as a whole, it does have a real income interpretation as reported above. 
Table 5: Growth of real income by country.

\begin{tabular}{lccc}
\hline & Armington & Monopolistic Competition \\
\hline China-3 & $(1)$ & $(2)$ & \\
Kazakhstan & $1.2 \%$ & $2.0 \%$ & $\mathrm{M}$ \\
Kyrgyzstan & $1.6 \%$ & $2.1 \%$ & $\mathrm{M}$ \\
Pakistan & $4.9 \%$ & $4.4 \%$ & \\
Tajikistan & $1.8 \%$ & $2.3 \%$ & $\mathrm{M}$ \\
Turkmenistan & $1.7 \%$ & $1.5 \%$ & \\
Uzbekistan & $0.3 \%$ & $0.0 \%$ & \\
\hline Aggregate & $0.8 \%$ & $1.0 \%$ & \\
\hline
\end{tabular}

Table 6. Growth in GVA, by country and sector

\begin{tabular}{lcccccc}
\hline & \multicolumn{2}{c}{ Armington } & \multicolumn{2}{c}{ Monopolistic Competition } \\
\cline { 2 - 7 } & Primary & Manuf. & Primary & Manuf. \\
\hline China-3 & $(1)$ & $(2)$ & $(3)$ & $(4)$ & \\
Kazakhstan & $-2 \%$ & $3 \%$ & $-2 \%$ & $4 \%$ & $\mathrm{M}$ \\
Kyrgyzstan & $3 \%$ & $2 \%$ & $3 \%$ & $3 \%$ & $\mathrm{M}$ \\
Pakistan & $6 \%$ & $-3 \%$ & $7 \%$ & $-6 \%$ & \\
Tajikistan & $1 \%$ & $3 \%$ & $2 \%$ & $4 \%$ & $\mathrm{M}$ \\
Turkmenistan & $4 \%$ & $0 \%$ & $4 \%$ & $-1 \%$ & \\
Uzbekistan & $2 \%$ & $0 \%$ & $3 \%$ & $-1 \%$ & \\
\hline
\end{tabular}

The model operates at the level of the cell, which gives a finer picture of the effect of the BRI. We summarize results in three scatter plots, figures 3-5. The horizontal axis of each is the direct effect of the decline in trade costs, and the vertical is the percentage change in real incomes. The direct effect is measured as an average of the reduction in the transport costs of export and imports experienced by each country. The straight lines show the line of best fit from linear OLS regression for which the slope and $\mathrm{R}^{2}$ are reported in the graphs.

Figure 3 gives the Armington case, corresponding to the first column of table 5. Several points stand out. First, all cells experience an increase in real per capita income, and the range of gains is quite dispersed, from close to zero to around $7 \%$. Second, as expected, there is a strong positive relationship between the direct effect and the full effect, with the direct effect accounting for $97 \%$ of the variance of the change in per capita income. Third, the cells that gain the most are in Kyrgyzstan, namely Osh city, Osh oblast, Naryn and Batken. While the direct effects reported on the x-axis are a mean of export and import weighted reductions in trade costs, Kyrgyzstan has the highest reduction in import costs, which fall by $11 \%$ at the country level (compared to $1-2 \%$ reductions elsewhere). This is driving the growth in real incomes in Kyrgyzstan.

Figure 4, monopolistic competition, allows for fuller adjustment in manufacturing, although holds labor immobile, fixed in its initial cell. Visually, the figure is similar to the previous, although the relationship 
between the direct reduction in trade costs and the real income growth is slightly less strong, with the former now explaining $84 \%$ of the variation in the latter. There is increased variation both within and across country, as the economy adjusts to the changing costs of trade. For example, while Kazakhstan's average per capita income growth is $2.1 \%$, this ranges from a minimum cell level growth of $1.25 \%$ (Shymkent) to a maximum of 6.3\% (Aqtau).

Figure 5 shows monopolistic competition with some (but not perfect) labor mobility between cells in each country. At the country aggregate level, the addition of labor mobility makes only very small differences to results (so was not reported in tables 2 and 3). But at the cell level, labor mobility narrows the variance in real income changes. People move into areas where the economy grows, dampening real wage growth in these cells by putting downward pressure on wages and upward pressure on demand for local services and rents. This results in lower variation between cells within countries. The slope of the regression line flattens somewhat, decreasing the difference in effect for those cells which gain the most versus those that gain the least. For example, in Kazakhstan the minimum remains Shymkent, but now at $1.6 \%$, and the maximum Aqtau, at $4.25 \%$. The population changes that bring about this leveling of per-capital incomes are - in proportionate terms - quite large in some places. The western oblasts of Kazakhstan (Aqtau, Atyrau and Aqtobe) experience population increases of respectively 25\%, $12 \%$ and $11 \%$. This is accompanied by declines in other areas in the country (a maximum decline of $4 \%$ in Shymkent). Of course, the decline is against a model assumption of constant total population; they are long run changes which will, in reality, be accompanied by changes in total national population.

The cell level detail enables a finer exploration of the reasons for the spatial variation in outcomes. Table 7 reports cross-cell regressions of outcome variables on the initial share of employment in manufacturing, and on direct trade cost changes, now split according to whether these are impacting imports (i.e. along routes through which a cell imports large values in the base period) or exports. Results are reported just for the case of monopolistic competition without labor mobility; they are qualitatively similar in other cases.

The results indicate that, first, the growth of manufacturing is positively correlated with the initial manufacturing share and with the decline in export trade costs, and negatively with the decline in import trade costs. The effects are significant and quantitatively important; a $1 \%$ fall in export trade costs leads to $4 \%$ increase in manufacturing output, as better connectivity enables countries to exploit regional advantage in manufactures. Second, the converse seems to be true for the primary sector; the initial share of manufacturing is negative and significant, as expected, and the decline in import trade costs is positively correlated with primary growth while a decline in export costs is negatively correlated with primary growth.

These asymmetric responses arise from the general equilibrium of the model, and the fact that the quantity response of manufacturing is more elastic than that of the primary sector. Monopolistic competition, with the consequent entry and exit of firms (and varieties), makes this sector more 'footloose' and more responsive to changes in trading opportunities. Thus, the results of Table 7 indicate that a cell receiving equal reductions in export and import costs could expect an expansion of manufactures and (small) contraction of the primary sector. ${ }^{14}$ It also points to the importance of the reduction in trade costs being (at least) reciprocal, i.e. with export cost reduction not being overwhelmed by import cost reduction. These things matter because, as indicated in column 1 of Table 7, it is

\footnotetext{
${ }^{14}$ In the Armington case the responsiveness of both sectors to the reduction in transport cost is more aligned; the equivalent regression shows that an equal reduction in export and import costs on average leads to a small positive expansion of both primary good and manufacturing production.
} 
reductions in export trade costs and growth of manufacturing that are associated with relatively larger increases in real income.

The degree to which import or export routes are affected also depends on whether or not the improved transport links foster regional trade or that with the rest of the world. Table 8 splits the reductions in trade costs according to whether they are with other cells in the region of study, or with the Rest of the World (RoW) through one of the four access points. The importance of the fall in export costs for manufacturing growth is particularly through links within the wider region, as better connectivity within the region allows for some clustering and higher manufacturing output growth. For real incomes in column one, however, whether the fall in trade costs is with the region or the rest of the world does not make a substantial difference.

Figure 3: Growth in real per capita incomes: Armington

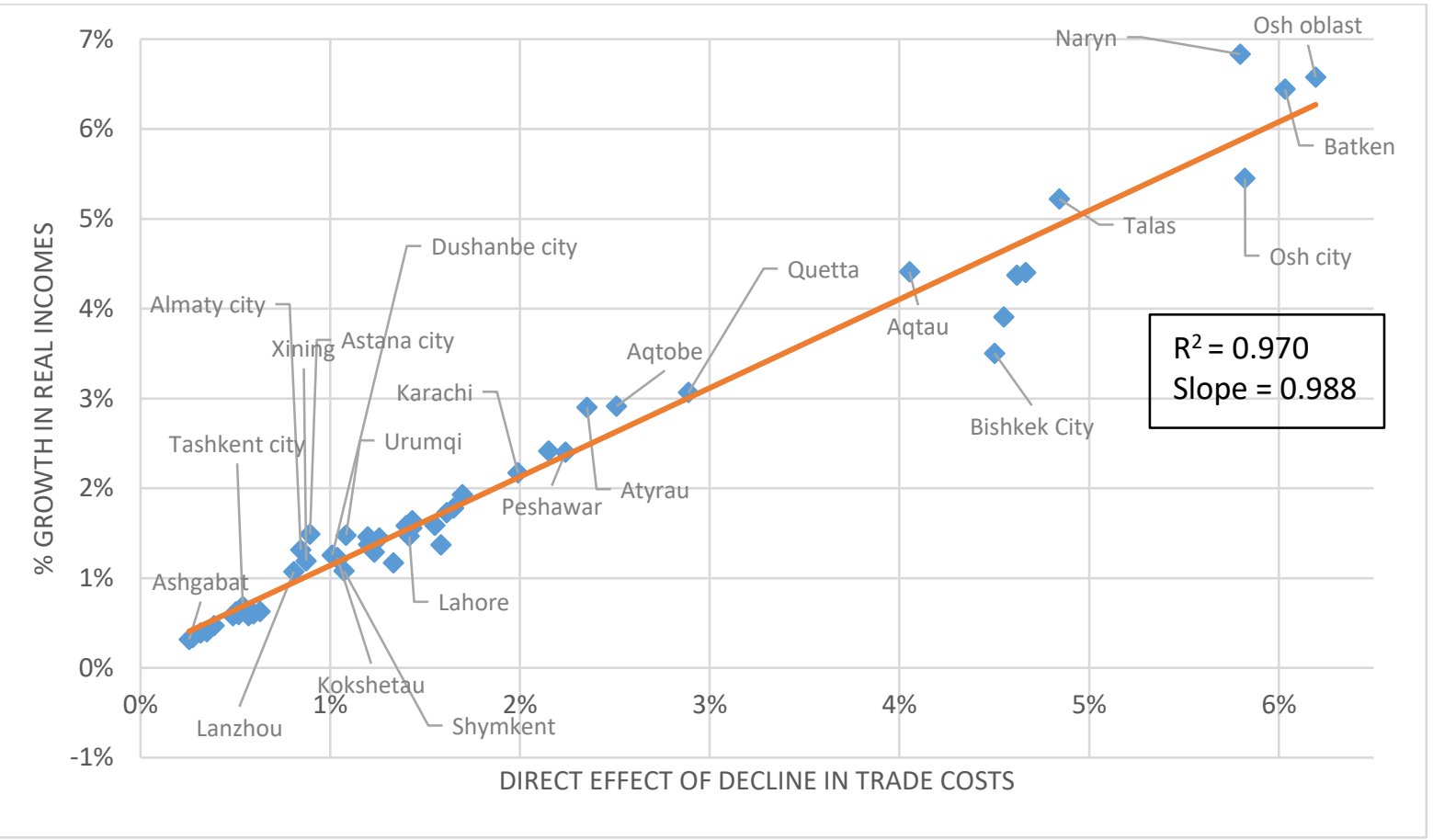


Figure 4: Growth in real per capita incomes: Monopolistic Competition, no labor mobility

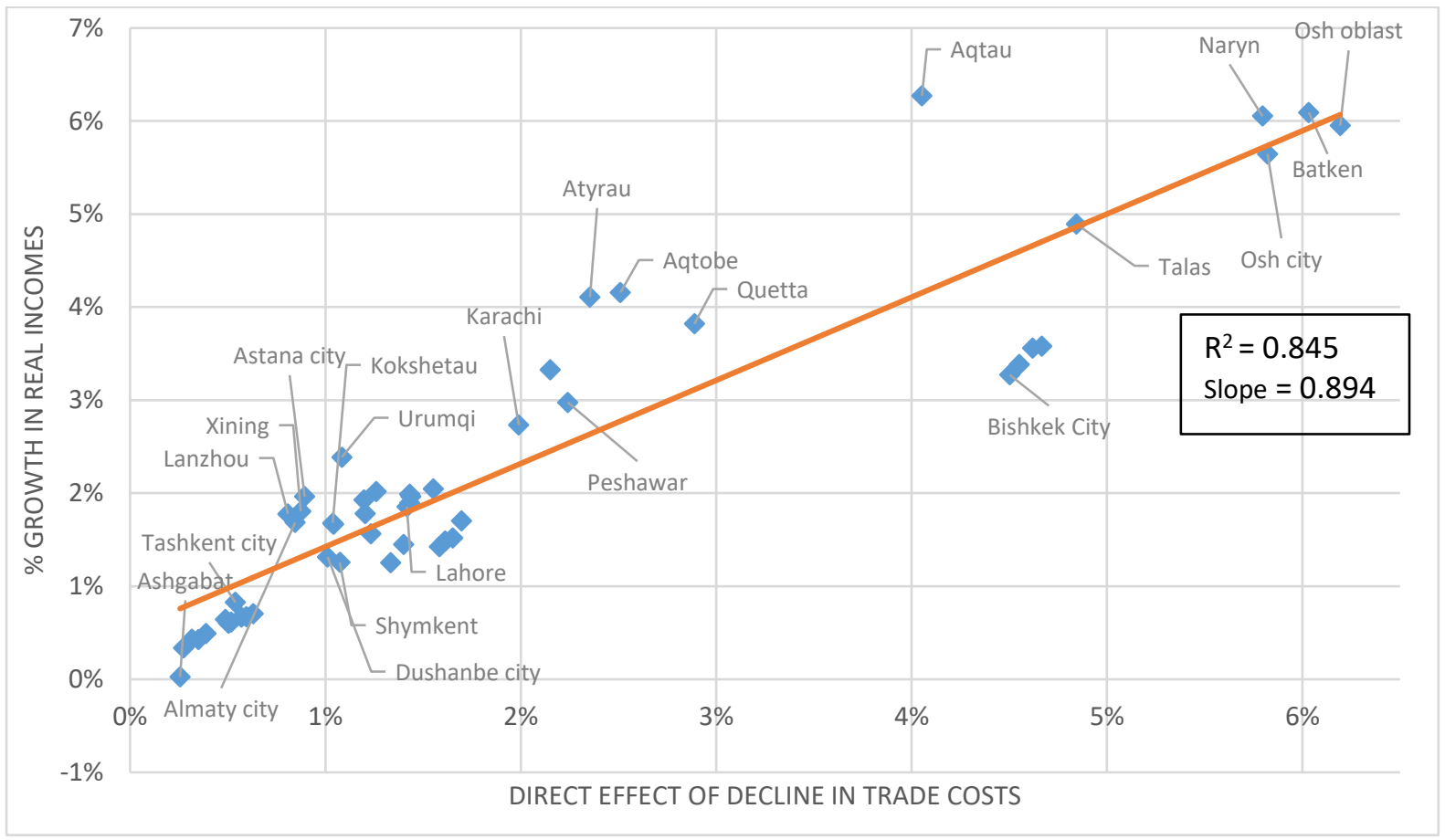

Figure 5: Growth in real per capita incomes: Monopolistic Competition and within-country labor mobility

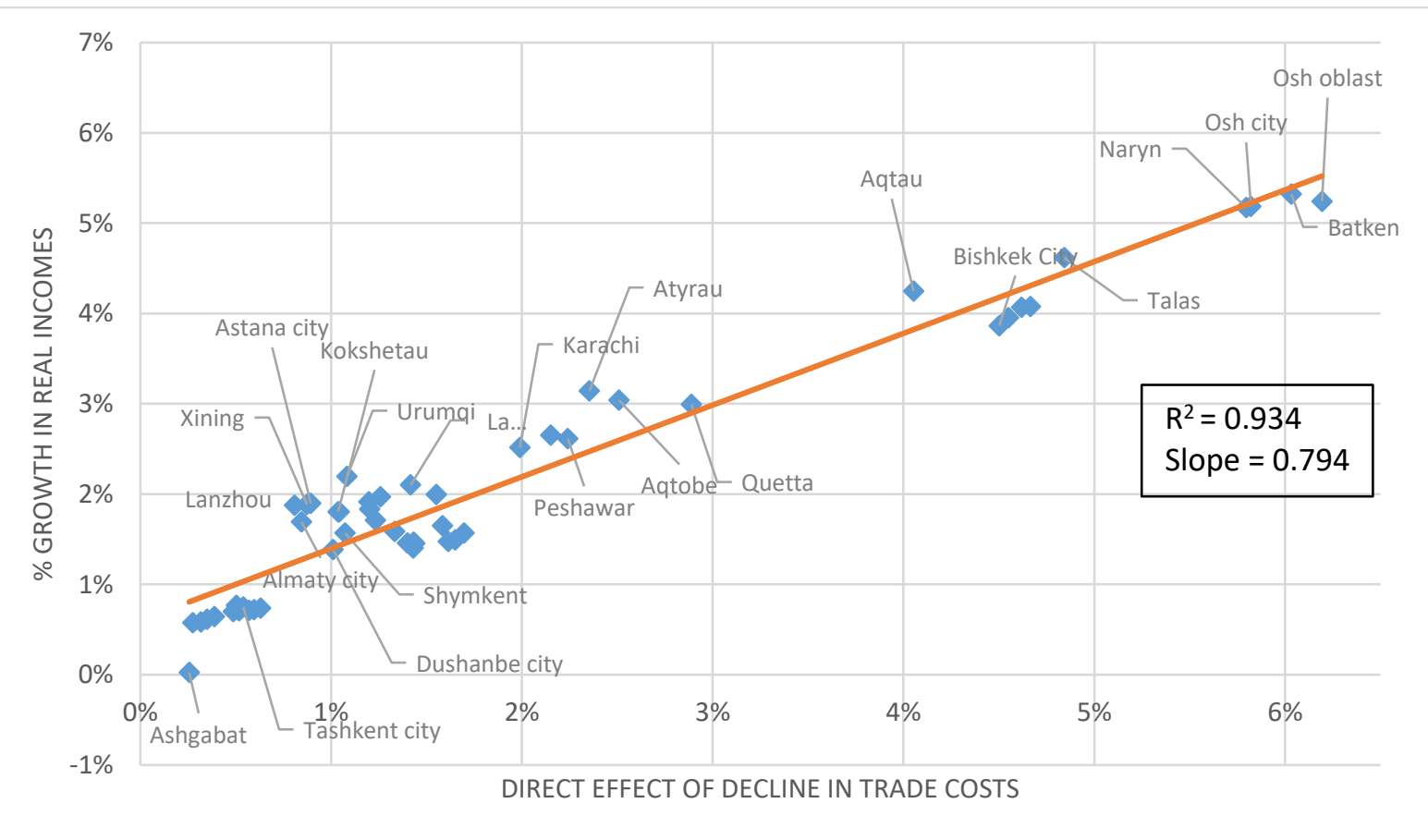


Table 7: OLS regression of impacts under Monopolistic Competition, on initial characteristics of cells and changes in trade costs

\begin{tabular}{lccc}
\hline & Real Income Growth & $\begin{array}{c}\text { Primary GVA } \\
\text { Growth }\end{array}$ & $\begin{array}{c}\text { Manufacturing GVA } \\
\text { Growth }\end{array}$ \\
\cline { 2 - 4 } & $(1)$ & $(2)$ & $(3)$ \\
\hline Share of Employment & 0.00612 & $-0.0565^{* *}$ & $0.164^{* * *}$ \\
in Manufacturing & $(0.00643)$ & $(0.0219)$ & $(0.0464)$ \\
& & & \\
Decline Export & $0.901^{* * *}$ & $-0.496^{*}$ & $3.932^{* * *}$ \\
Trade Cost & $(0.0830)$ & $(0.252)$ & $(0.598)$ \\
& & & $-0.750^{* * *}$ \\
Decline Import & $0.301^{* * *}$ & $0.414^{* * *}$ & $(0.159)$ \\
Trade Cost & $(0.0220)$ & $(0.0672)$ & $-8.272^{* * *}$ \\
& & & $(2.211)$ \\
Constant & -0.268 & $4.261^{* * *}$ & 52 \\
& $(0.307)$ & $(0.963)$ & 0.622 \\
\hline Observations & 52 & 49 & 0.617 \\
Adjusted $R^{2}$ & 0.898 & . & \\
\hline
\end{tabular}

OLS regression with all variables expressed as percentages. Standard errors in parentheses ${ }^{*} p<0.10,{ }^{* *} p<0.05,{ }^{* * *} p<0.01$

Table 8: OLS regression of impacts under Monopolistic Competition, on initial characteristics of cells and changes in trade costs

\begin{tabular}{lccc}
\hline & Real Income Growth & $\begin{array}{c}\text { Primary GVA } \\
\text { Growth }\end{array}$ & $\begin{array}{c}\text { Manufacturing GVA } \\
\text { Growth }\end{array}$ \\
\cline { 2 - 4 } & $(1)$ & $(2)$ & $(3)$ \\
\hline $\begin{array}{l}\text { Share of Employment } \\
\text { in Manufacturing }\end{array}$ & 0.00635 & $-0.0632^{* * *}$ & $0.182^{* * *}$ \\
& $(0.00680)$ & $(0.0226)$ & $(0.0466)$ \\
Decline Export & $0.940^{* * *}$ & $-1.501^{* *}$ & $5.116^{* * *}$ \\
Trade Cost with Region & $(0.251)$ & $(0.738)$ & $(1.719)$ \\
& & & \\
Decline Export & $0.892^{* * *}$ & -0.281 & $2.205^{* *}$ \\
Trade Cost with RoW & $(0.148)$ & $(0.443)$ & $(1.016)$ \\
& & & -0.647 \\
Decline Import & 0.268 & $1.286^{* *}$ & $(1.332)$ \\
Trade Cost with Region & $(0.195)$ & $(0.572)$ & $-0.628^{* *}$ \\
& & & $(0.259)$ \\
Decline Import & $0.306^{* * *}$ & $0.280^{* *}$ & \\
Trade Cost with RoW & $(0.0379)$ & $(0.113)$ & $-8.808^{* * *}$ \\
Constant & -0.273 & $4.424 * * *$ & $(2.168)$ \\
\hline Observations & $(0.317)$ & $(0.972)$ & 52 \\
Adjusted $R^{2}$ & 52 & 49 & 0.645 \\
\hline
\end{tabular}

OLS regression with all variables expressed as percentages. Standard errors in parentheses ${ }^{*} p<0.10,{ }^{* *} p<0.05,{ }^{* * *} p<0.01$. 


\section{3: BRI and economic geography: Productivity and clustering}

The changes reported above yield real income gains somewhat larger than direct effects and, if labor is mobile, some quite large changes in the distribution of population and economic activity. We now explore more radical possibilities in which localization economies are present in the manufacturing sector so that an increase in economic activity in a particular cell and sector has a positive effect on productivity in the cell-sector. As discussed in section 4, these scale economies are set such that the elasticity of productivity with respect to the output in the cell-sector has a mean value of 0.07 and a maximum value of 0.088 , numbers at the mid-to-top end of the range of agglomeration economies that are found by empirical work, largely from studies in high income countries. The presence of such effects means that there are benefits from clustering of firms in a particular place and as a consequence there may be multiple equilibria; firms derive advantage not solely from the fundamental characteristics of each place, but from the presence of other related firms. ${ }^{15}$ In this world the actual equilibrium - and that selected by an economic model such as this - is likely to be path dependent and highly sensitive to small variations in initial conditions. This means that exact predictions of where clusters form are more than usual subject to doubt. However, development of clusters in some cells is a possible outcome of the improvement in connectivity, and merits the exploration that follows.

Table 9 reports real income effects at the country level; columns (1) and (2) are as in table 5, and columns (4) and (5) add the localization economies (increasing returns) without and with labor mobility. In the absence of labor mobility, real income gains are somewhat larger than in previous cases, exceeding Armington effects by $60 \%$. Structural change is also greater (Table 8, comparing columns (1) and (2) with (3) and (4)).

Without labor mobility, the returns to scale created by clustering of firms is choked off by constraints on the supply of labor. The final column of table 9 relaxes this constraint by allowing limited mobility of labor. The real income effect of the BRI becomes nearly twice as large as in the Armington setting. Structural change (Table 9 columns (5) and (6)) increases and Kazakhstan, China-3 and Pakistan in particular are beneficiaries with 5-8\% growth in manufacturing and a 2.4-5.6\% increases in real income.

${ }^{15}$ For analytical investigation of these effects see Fujita et al. (1999). 
Table 9: Real income gains by country.

\begin{tabular}{lcccc}
\hline & & \multicolumn{3}{c}{ Real Income Growth } \\
\cline { 2 - 5 } & Armington & $\begin{array}{c}\text { Monopolistic } \\
\text { competition }\end{array}$ & $\begin{array}{c}\text { Increasing } \\
\text { returns }\end{array}$ & $\begin{array}{c}\text { Increasing } \\
\text { returns \& labor } \\
\text { mobility }\end{array}$ \\
\hline China-3 & $(1)$ & $(2)$ & $(3)$ & $(4)$ \\
Kazakhstan & $1.2 \%$ & $2.0 \%$ & $2.4 \%$ & $2.4 \%$ \\
Kyrgyzstan & $1.6 \%$ & $2.0 \%$ & $2.5 \%$ & $5.6 \%$ \\
Pakistan & $4.9 \%$ & $4.4 \%$ & $3.9 \%$ & $5.1 \%$ \\
Tajikistan & $1.8 \%$ & $2.3 \%$ & $2.5 \%$ & $2.7 \%$ \\
Turkmenistan & $1.7 \%$ & $1.5 \%$ & $1.2 \%$ & $0.9 \%$ \\
Uzbekistan & $0.3 \%$ & $0.0 \%$ & $-0.2 \%$ & $-0.3 \%$ \\
\hline Aggregate & $0.8 \%$ & $0.9 \%$ & $1.1 \%$ & $1.5 \%$ \\
\hline
\end{tabular}

Table 10. Growth in GVA, by sector

\begin{tabular}{lcccccc}
\hline & \multicolumn{2}{c}{$\begin{array}{c}\text { Monopolistic } \\
\text { competition }\end{array}$} & \multicolumn{2}{c}{ Increasing returns } & \multicolumn{2}{c}{$\begin{array}{c}\text { Increasing returns \& } \\
\text { labor mobility }\end{array}$} \\
\cline { 2 - 5 } \cline { 5 - 7 } & Primary & Manuf. & Primary & Manuf. & Primary & Manuf. \\
\hline China-3 & $(1)$ & $(2)$ & $(3)$ & $(4)$ & $(5)$ & $(6)$ \\
Kazakhstan & $-2 \%$ & $4 \%$ & $-2 \%$ & $5 \%$ & $-2 \%$ & $5 \%$ \\
Kyrgyzstan & $3 \%$ & $3 \%$ & $2 \%$ & $4 \%$ & $5 \%$ & $8 \%$ \\
Pakistan & $7 \%$ & $-6 \%$ & $8 \%$ & $-9 \%$ & $8 \%$ & $-5 \%$ \\
Tajikistan & $2 \%$ & $4 \%$ & $2 \%$ & $5 \%$ & $2 \%$ & $5 \%$ \\
Turkmenistan & $4 \%$ & $-1 \%$ & $5 \%$ & $-2 \%$ & $8 \%$ & $-9 \%$ \\
Uzbekistan & $3 \%$ & $-1 \%$ & $3 \%$ & $-1 \%$ & $3 \%$ & $-1 \%$ \\
\hline
\end{tabular}

Clustering and localization economies occur at the cell level, and population movement is between cells within countries. It is therefore at the cell level that the story appears most clearly, as shown in figures 6 and 7 (shown on smaller vertical scales than preceding scatter plots). With increasing returns and labor mobility, cells in manufacturing areas of Western Kazakhstan experience increases in real incomes in excess of $10 \%$. Driving this is large growth of manufacturing, which doubles in size in Aqtobe, Aqtau, and increases to four times its initial output in Qostanay in Kazakhstan. This occurs alongside population growth, enabling scale economies to be realized. Similar, though smaller, transformations occur in Quetta in Pakistan and Osh city in Kyrgyzstan.

This is also clear in the Table 11, which shows the correlation between the falls in trade costs and real income growth under Armington, Monopolistic Competition, and Increasing Returns with Labor Mobility. First, while base manufacturing shares have little impact on income growth in the Armington setting (and in fact, a slight negative one), once increasing returns to scale are considered, cells with higher manufacturing employment shares are better able to reap the benefits of declines in trade costs. Second, the impact of reductions in import costs remains similar in the three settings, influencing prices and boosting real incomes. Third, however, the reduction in export trade costs has increasing impact 
on real income growth across the three settings; when there are increasing returns to scale the falls in the cost of transporting exports to destinations allow cells to specialize, growing clusters of manufacturing, and hence boosting productivity and output.

An important further implication of this setting is that labor mobility widens intra-country income differentials, rather than narrowing them as we saw in the discussion of figures 4 and 5. Thus, continuing to take cells in Kazakhstan as an example, with increasing returns and no labor mobility, Aqtau's real income increase is $8 \%$ and Shymkent's is $1 \%$. With labor mobility, these become $12 \%$ and $2 \%$. Booming places experience both population growth and further income growth because of the effects of localization economies and increasing returns to scale in their productive sectors, this outweighing the effects of falling labor-to-land ratios. This amplification of effects is consistent with the equilibrium being stable, although if labor was even more mobile than we have assumed, this would be an unstable situation; further mobility would follow, sucking population into centers and depopulating other areas.

While the message that clustering may occur and bring with it gains is robust, we emphasize that identifying the precise places where this happens is not robust. Quite small initial differences between places may give the initial advantage that allows the cluster to form and grow: the data used in this model is not accurate enough to predict this with confidence, and local policy measures not captured in the model will influence outcomes. Furthermore, some cities lose population; this is a consequence of our assumption that total population in each country is fixed: over the time scale of this long-run experiment aggregate population growth will likely mean that all cells gain population.

Figure 6: Growth in real per capita incomes: Increasing Returns and Labor Mobility.

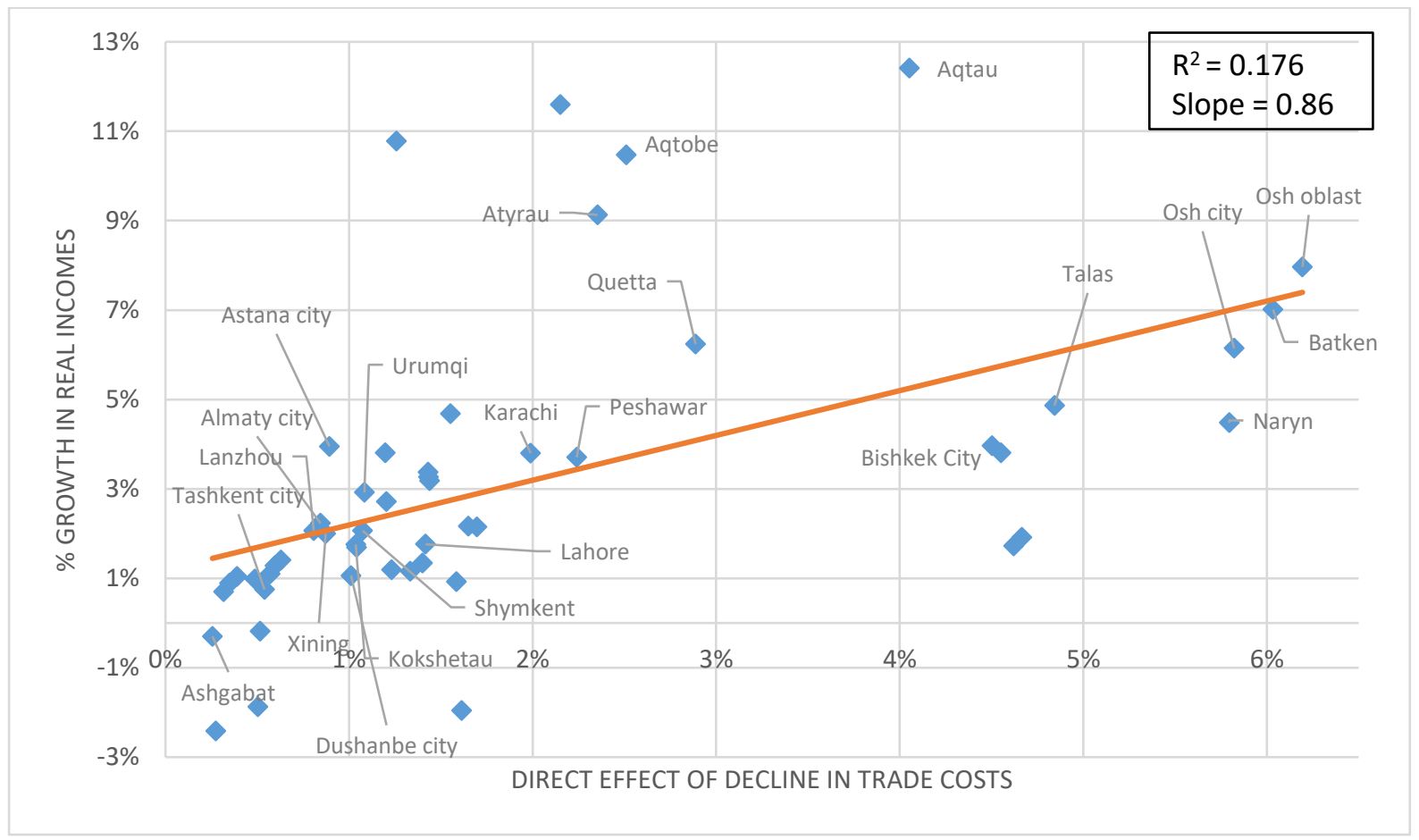


Figure 7: Change in cell population, Increasing Returns and Labor Mobility.

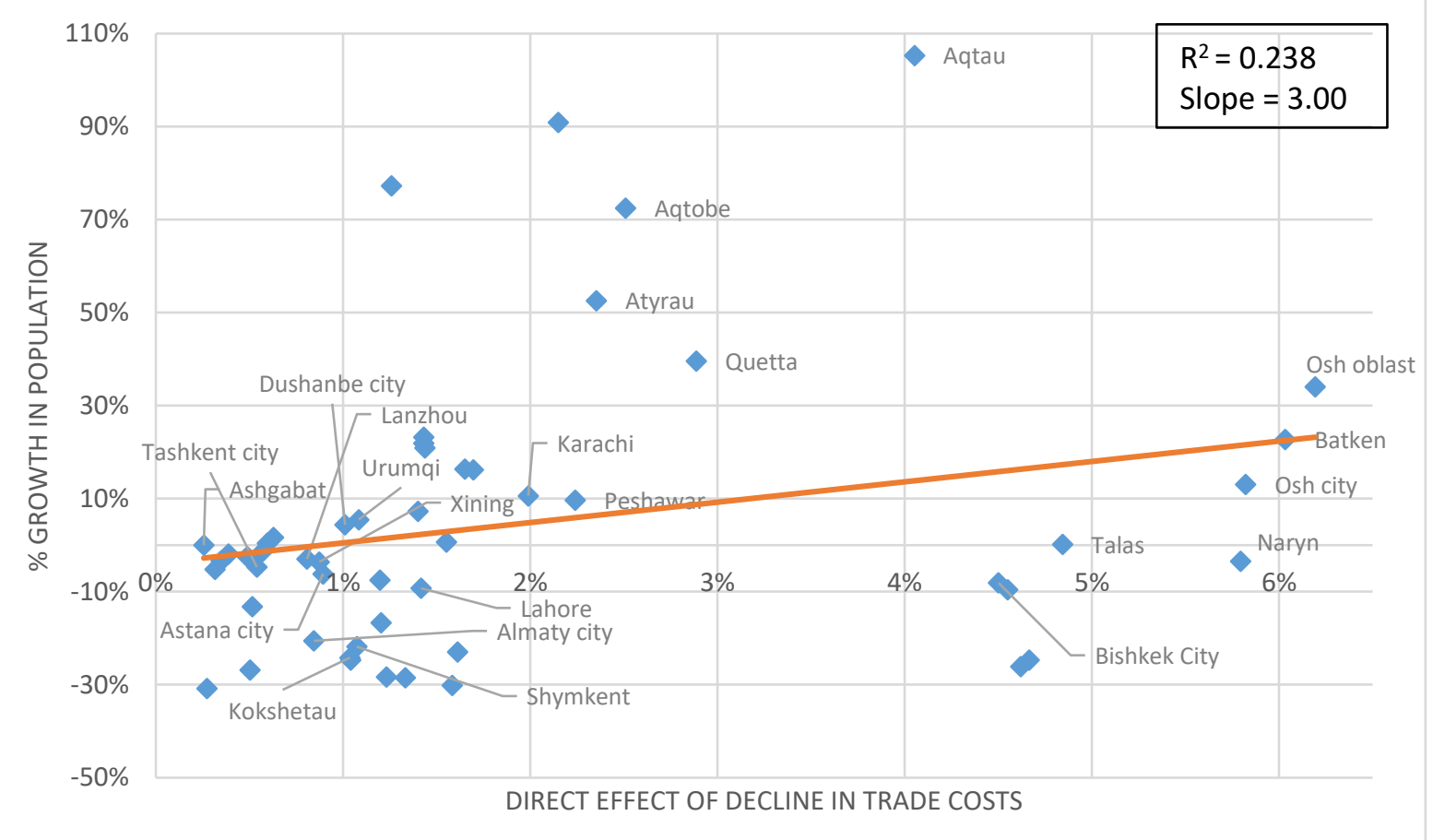

Table 11: OLS regression of impacts on real income growth under different settings, on initial characteristics of cells and changes in trade costs.

\begin{tabular}{lccc}
\hline & Armington & $\begin{array}{c}\text { Monopolistic } \\
\text { Competition }\end{array}$ & $\begin{array}{c}\text { IRS and Labor } \\
\text { Mobility }\end{array}$ \\
\cline { 2 - 4 } & $(1)$ & $(2)$ & $(3)$ \\
\hline $\begin{array}{l}\text { Share of Employment } \\
\text { in Manufacturing }\end{array}$ & $-0.00923^{*}$ & 0.00612 & $0.0459^{*}$ \\
Decline Export & $(0.00506)$ & $(0.00643)$ & $(0.0245)$ \\
Trade Cost & $0.512^{* * *}$ & $0.901^{* * *}$ & $2.628^{* * *}$ \\
& $(0.0653)$ & $(0.0830)$ & $(0.316)$ \\
Decline Import & & & $0.236^{* * *}$ \\
Trade Cost & $0.356^{* * *}$ & $0.301^{* * *}$ & $(0.0838)$ \\
Constant & $(0.0173)$ & $(0.0220)$ & $-3.216^{* * *}$ \\
& & & $(1.167)$ \\
\hline Observations & $0.491^{* *}$ & -0.268 & 52 \\
Adjusted $R^{2}$ & $(0.241)$ & $(0.307)$ & 0.629 \\
\hline
\end{tabular}

OLS regression with all variables expressed as percentages. Standard errors in parentheses ${ }^{*} p<0.10,{ }^{* *} p<0.05,{ }^{* * *} p<0.01$ 


\section{The BRI: Infrastructure improvements and border effects}

A large component of transport times between countries in Central Asia and with the rest of the world is the time spent at borders. De Soyres et al. (2018) produce separate estimates of changes in border delays based on reductions in importing and exporting times from the 'trading across borders' section of the World Bank's Doing Business Database. ${ }^{16}$ Table 12 combines these estimates with those of the preceding section to give combined reductions in transport time. The table indicates that the estimated reduction in border times yield greater average time saving than do the physical investments alone (the simple average of numbers in table 12 is a $39 \%$ reduction in travel times, as compared to a $15 \%$ average reduction in the previous experiment, the average of numbers in table 4). Furthermore, there are considerable differences in the geographical pattern of these changes. For example, reduced border delays bring Kyrgyzstan very large reductions in transport times, with many falling by over $60 \%$. China-3 has lower travel times with Pakistan and improved access to the rest of the world through Gwadar.

Table 12: Reduction in Average Transport Time, infrastructure improvement and border effects: Country-to-country averages.

\begin{tabular}{lccccccc}
\hline & China- & Kazakhstan & Kyrgyzstan & Pakistan & Tajikistan & Turkmenistan & Uzbekistan \\
\hline China-3 & 3 & & & & & & \\
Kazakhstan & $42 \%$ & $42 \%$ & $63 \%$ & $67 \%$ & $41 \%$ & $31 \%$ & $45 \%$ \\
Kyrgyzstan & $63 \%$ & $37 \%$ & $0 \%$ & $43 \%$ & $61 \%$ & $64 \%$ & $64 \%$ \\
Pakistan & $67 \%$ & $27 \%$ & $43 \%$ & $32 \%$ & $27 \%$ & $24 \%$ & $27 \%$ \\
Tajikistan & $41 \%$ & $61 \%$ & $61 \%$ & $27 \%$ & $0 \%$ & $36 \%$ & $46 \%$ \\
Turkmenistan & $31 \%$ & $71 \%$ & $64 \%$ & $24 \%$ & $36 \%$ & $0 \%$ & $45 \%$ \\
Uzbekistan & $45 \%$ & $51 \%$ & $64 \%$ & $27 \%$ & $46 \%$ & $45 \%$ & $17 \%$ \\
\hline Chongqing & $0 \%$ & $35 \%$ & $56 \%$ & $59 \%$ & $36 \%$ & $27 \%$ & $45 \%$ \\
Gwadar & $63 \%$ & $23 \%$ & $40 \%$ & $28 \%$ & $31 \%$ & $28 \%$ & $31 \%$ \\
Istanbul & $48 \%$ & $34 \%$ & $36 \%$ & $16 \%$ & $21 \%$ & $16 \%$ & $37 \%$ \\
Moscow & $52 \%$ & $36 \%$ & $37 \%$ & $34 \%$ & $26 \%$ & $23 \%$ & $38 \%$ \\
\hline
\end{tabular}

We have run the model for this larger experiment, and briefly report and comment on selected results. A summary comparison of the two policy experiments, under four adjustment scenarios, is given in figure $8 \mathrm{a}$ (infrastructure alone) and $8 \mathrm{~b}$ (infrastructure plus lower border costs). The combined experiments gives direct effects more than twice as large, at 3.4\% versus 1.4\% (aggregate, right hand block of $8 \mathrm{a}$ and $8 \mathrm{~b}$ ), and full effects (with increasing returns and labor mobility) over three times as large, amounting to a $8.8 \%$ increase in per capita income for the region as a whole.

Within this aggregate effect on the region there are substantial differences in national impacts. These are due to details of changes in the transport network and are hard to generalize about. For example, the direct effects for Kyrgyzstan are much larger in this case than with infrastructure alone. As a central

\footnotetext{
16 For any border, the data on "Border Compliance" and the total delay is assumed to be the sum of export time from the exporting country and the import time from the importing country. Documentary compliance is not included as it does not relate to travel time. All data are available at http://www.doingbusiness.org/data/exploretopics/trading-across-borders.
} 
country in the BRI network, it gains from a fall in transport costs with every major trading partner, both within the region and in the rest of the word. The Armington setting shows that Kyrgyzstan experiences an income gain of $12.8 \%$, compared to $4.8 \%$ in the infrastructure only scenario. Once full adjustment occurs, with increasing returns to scale and labor mobility this rises to a gain of $17.7 \%$. The large direct effect induces a substantial economic shift; despite being a major manufacturing importer initially, cities within Kyrgyzstan, particularly Osh, develop as economic clusters and see increases in both productivity and manufacturing output. The creation of these clusters generates increasing returns to scale and begins to allow the country to establish itself as a local manufacturing hub. Other provinces within the country with slightly lower levels of base manufacturing employment shares see growth driven by increased primary good production.

The initial manufacturing centers in the above analysis - China-3, Kazakhstan, Pakistan, and to a lesser extent Uzbekistan - continue to do well. China-3, already a sizable economy within the region, has a direct increase in income under the Armington setting of 5.5\%, over four and a half times that in the infrastructure scenario. Combined with the initial large manufacturing base, China- 3 can exploit these large falls in trade costs to reap income growth of $12.4 \%$, enhancing pre-existing productive clusters. Kazakhstan, Uzbekistan, and Pakistan also observe high income growth, though not at the same rate as China-3. These countries have large manufacturing bases and are able to reap the benefits of lower trade costs throughout the region. They do however simultaneously experience increased import competition from China-3, Kyrgyzstan and the rest of the world. As a result, the size of the income growth, though still large, does not reach the levels obtained by Kyrgyzstan.

Finally, for Tajikistan and Turkmenistan, countries with very little in the way of manufacturing, full adjustment gives smaller economic gains than occur with Armington adjustment. Tajikistan, though faced with one of the largest falls in transport costs which leads to gains of $6.2 \%$ under Armington, cannot convert this into growth in manufacturing. Simultaneously, primary goods can be imported at far lower prices, which while offering lower prices to consumers also competes against local production, reducing gains to $1 \%$, only marginally more than under the infrastructure scenario alone. For Turkmenistan performance is even worse. With little in the way of manufacturing and a less competitive economy, the reduction in trade costs leads to a substantial fall in incomes. Reduced trade costs are not sufficient in themselves to boost the local economy, and import competition may in fact damage incomes when the initial productive capacity is lower compared to that in potential trading partners. 
Figure 8a: Real income gains by country: infrastructure improvements

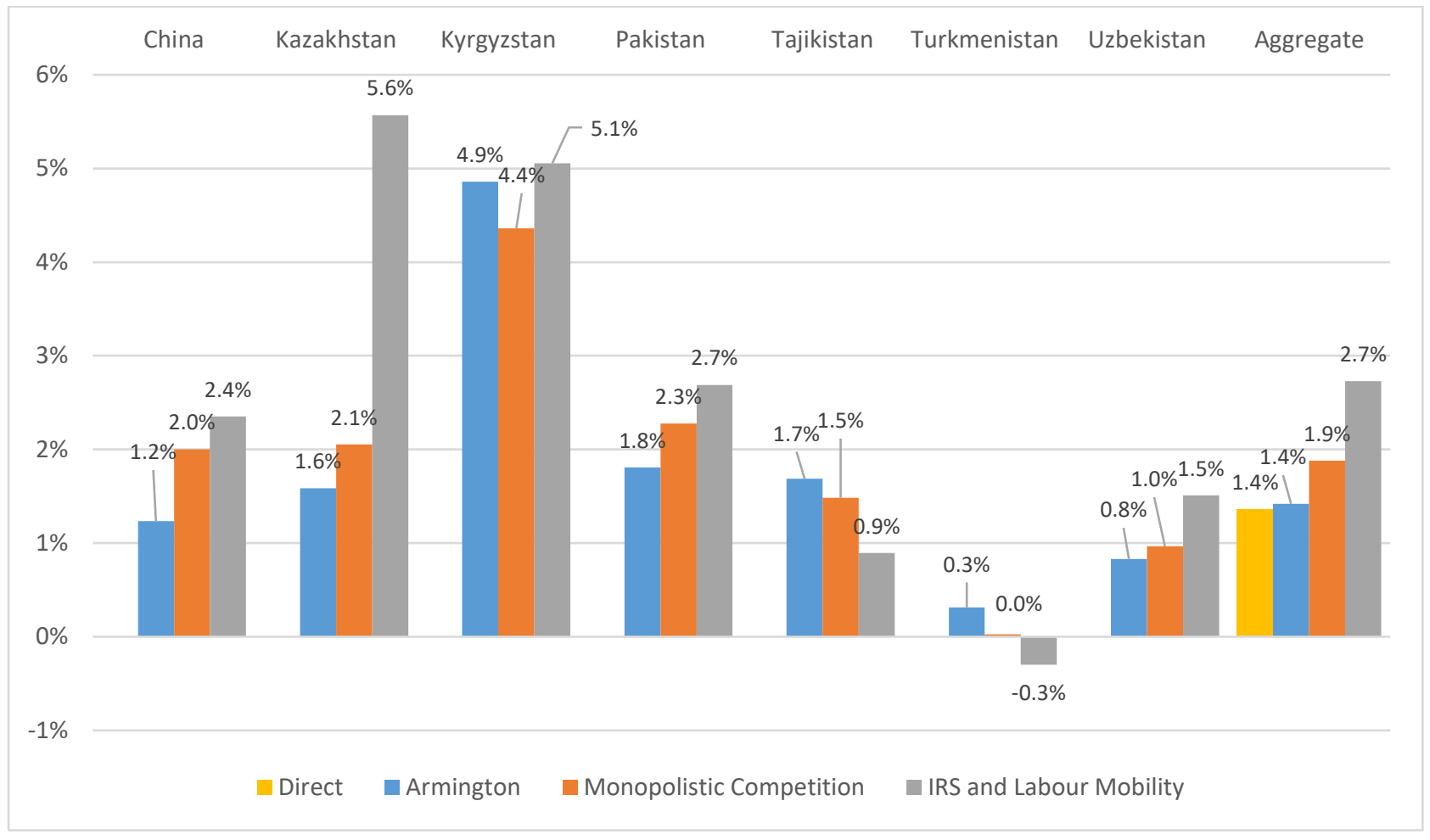

Figure 8b: Real income gains by country; infrastructure improvements and border effects

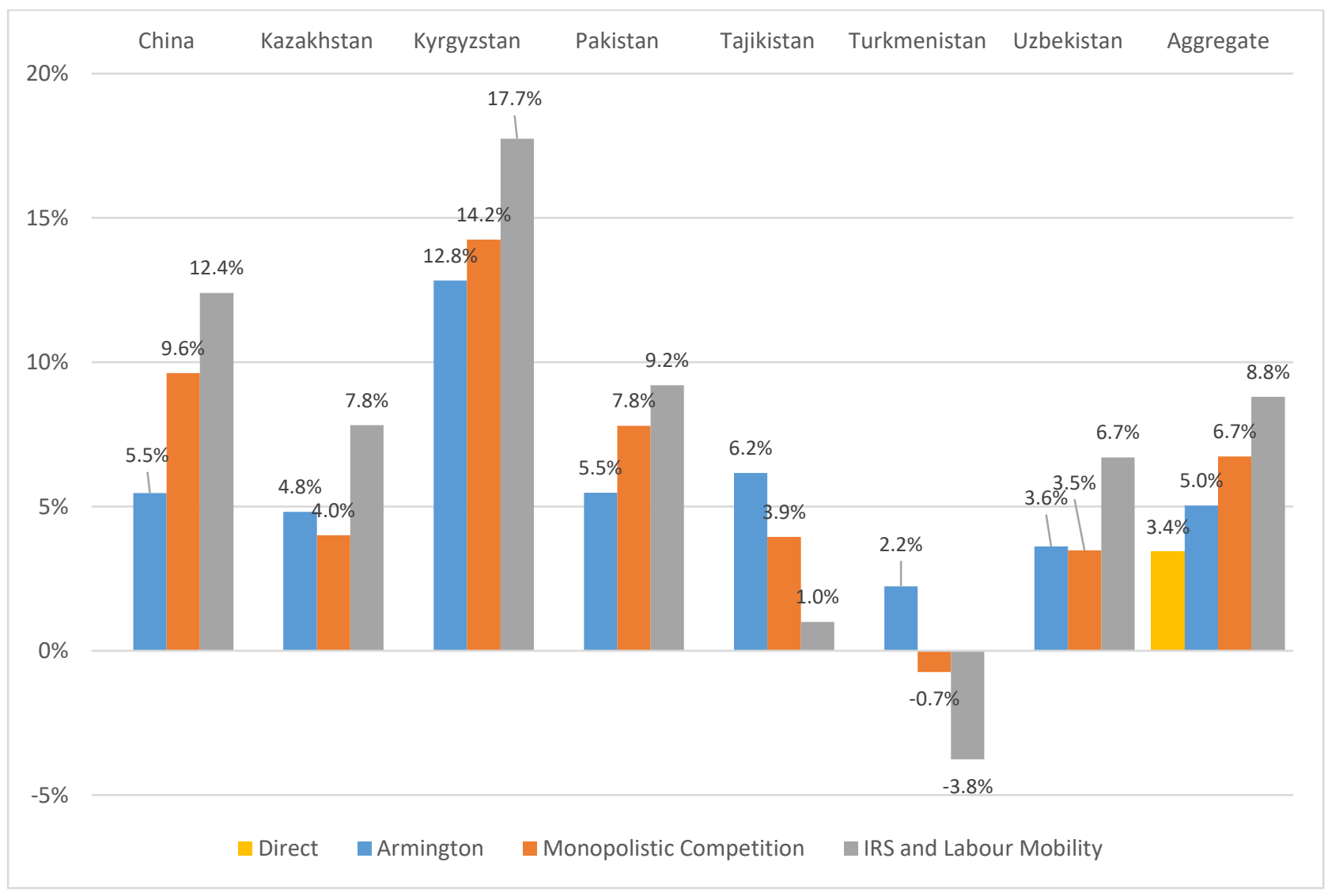




\section{Conclusions}

The BRI offers Central Asia the prospect of large improvements in connectivity, linking places within the region to each other as well as improving connections to the rest of the world. The tools of international economics and economic geography provide ways of thinking about the effects of such improvements, and this paper applies these tools in a quantitative model of the region. The paper presents a series of scenarios describing different economic environments and adjustment possibilities. In particular, we show how the presence of agglomeration economies in the manufacturing sector, together with intra-country migration, creates opportunities for quite radical changes in the economic structure of some countries, and also yields large aggregate benefits.

We start with a conservative approach in which few factors are mobile, meaning that adjustment rapidly runs into diminishing returns; direct benefits of around 1.4\% of GDP (in aggregate across the region) get somewhat amplified by economic adjustment, up to around $1.9 \%$ of GDP. We then go beyond this to increase the scale of possible response, letting more things be mobile (firms and, to some extent, workers) and adding increasing returns to scale and agglomeration economies to some productive sectors. This produces much larger quantity responses, and takes aggregate real income gains up to around 3\% of GDP, with gains for some countries exceeding 5\%. These gains flow from the performance of particular geographical cells that are able to increase manufacturing production and expand population, reaping productivity improvements as this happens. The top performing cells in the entire region see per capita real income gains of as much as $12 \%$, coupled with a doubling of the local population; the worst performing experience small real income declines and lose a substantial fraction of their population. Importantly, labor mobility, which without increasing returns to scale served to limit regional inequalities, can now increase regional inequalities. Whereas in a traditional model labor mobility reduces inequality, with increasing returns, booming regions with growing populations benefit from rising productivity and a virtuous circle of growth.

An exercise of this type faces many uncertainties, of which two are particularly critical. The first is that the BRI is a series of different projects, some infrastructure, others to do with logistics handling and border controls, and all combining to reshape a complete transport network. The direct impacts of these changes on travel times and hence on measures of transport costs are hard to estimate. A reduction in tariffs or the construction of a particular segment of road or rail may be a fairly clearly defined policy change, but this is not so in the case of the package of measures involved in the BRI. As we have shown, the combined experiment of infrastructure improvement plus facilitation of border crossings has quite different impacts on travel times, yielding considerably larger real income gains and relocation effects. Our work has built on the work of de Soyres et al. (2018) which, while thorough and careful in its construction, leaves many questions open due to the large degree of uncertainty about the BRI itself.

The second uncertainty is the way in which economies in the region respond to these changes in connectivity. This is particularly important since some areas in the region will experience changes in connectivity that go well beyond the usual economics framework of marginal change. The research literature, particularly in economic geography, suggests that such non-marginal changes may have large impacts. In the presence of economies of scale and agglomeration, places that experience an increase in activity may achieve productivity growth, and this will amplify change as clusters of economic activity develop. The present paper is innovative in so far as it captures these effects by including localization economies in the manufacturing sector. Doing this raises modeling issues concerning the best way to model localization economies, the possibilities that equilibria may become unstable (a problem we solve by only allowing limited labor mobility), and the inherent unpredictability about the 
exact location of clusters of activity. It means that the results we present are illustrative rather than predictive, but we think it important to confront and explore these mechanisms which are widely believed to be present. Results in the paper point to the possibility that the BRI could be a catalytic force for reshaping the economic geography of the region. Whether - and where - it does so will depend on numerous other aspects of the economic environment and economic policy, not least policy makers' responses to regionally divergent growth paths.

\section{References}

Alder, Simon, (2019). "Chinese roads in India: The effect of transport infrastructure on economic development." Univ. North Carolina, Chapel Hill

Allen, Treb and Costas Arkolakis, (2019) "The Welfare Effects of Transportation Infrastructure Improvements" Working Paper.

Anderson, James E and Eric van Wincoop, (2004) “Trade Costs," Journal of Economic Literature, 42 (3), 691-751.

Baum-Snow, N., J.V. Henderson, M.A. Turner, Q. Zhang \& L. Brandt, (2018) 'Does investment in highways help or hurt hinterland city growth', NBER working paper 24596.

Caliendo, L. and F. Parro, (2014) 'Estimates of the Trade and Welfare Effects of NAFTA', Review of Economic Studies, 82, 1-44.

Center for International Earth Science Information Network - CIESIN - Columbia University. 2016.

'Gridded Population of the World, Version 4 (GPWv4): Population Count Adjusted to Match 2015

Revision of UN WPP Country Totals.' Palisades, NY: NASA Socioeconomic Data and Applications Center (SEDAC). http://dx.doi.org/10.7927/H4SF2T42.

Combes, P-P. and L. Gobillon. (2015). The Empirics of Agglomeration Economies. In G. Duranton, V, Henderson, and W. Strange (eds.) Handbook of Regional and Urban Economics, volume 5A. Amsterdam: Elsevier, 247-348.

de Soyres, F., A. Mulabdic, S. Murray, N. Rocha, and M. Ruta, (2019) "How Much Will the Belt and Road Initiative Reduce Trade Costs?”, International Economics, 159, 151-164.

de Soyres, F., A. Mulabdic, and M. Ruta, (2020) "Common Transport Infrastructure; a quantitative model and estimates from the Belt and Road Initiative", Journal of Development Economics, forthcoming.

Defourny, P. (2017) 'ESA Land Cover Climate Change Initiative (Land_Cover_cci): Land Cover Maps, v2.0.7.' Centre for Environmental Data Analysis.

Djankov, Simeon, Caroline Freund, and Cong S Pham, (2010) "Trading on Time," Review of Economics and Statistics, 92 (1), 166-173.

Donaldson, Dave, (2018) "Railroads of the Raj: Estimating the Impact of Transportation Infrastructure," American Economic Review, 108 (4-5), 899-934.

Duranton, G., P. M. Morrow, and M. A. Turner, (2014) "Roads and Trade: Evidence from the US," The Review of Economic Studies, 81 (2), 681-724.

Fajgelbaum, Pablo and Stephen Redding, (2014) "External Integration, Structural Transformation and Economic Development: Evidence from Argentina 1870-1914,” NBER Working Paper 20217.

Fujita, M., P. Krugman and A.J. Venables (1999) 'The spatial economy; cities, regions and international trade', MIT press, Cambridge MA. 
Gaulier, G. and Zignago, S. (2010), 'BACI: International Trade Database at the Product-Level. The 1994-2007 Version', CEPII Working Paper, N²010-23

Glaeser, E. and W. Xiong. (2018), 'Urban productivity in the developing world', Oxford Review of Economic Policy, 33.3, 373-404.

Hummels, David L and Georg Schaur, (2013) "Time as a Trade Barrier," American Economic Review, 103 (7), 2935-2959.

Lall, Somik V. and Lebrand, Mathilde, (2019) "Who wins, who loses? Understanding the Spatially Differentiated Effects of Belt and Road within Central Asia".

Melo, Patricia C., Daniel J. Graham, and Robert B. Noland. (2009) "A meta-analysis of estimates of urban agglomeration economies." Regional science and Urban Economics 39.3: 332-342

OECD (2018) 'OECD Business and Finance Outlook', OECD, Paris.

Redding, Stephen J, (2016) "Goods Trade, factor mobility and welfare," Journal of International Economics, 101, 148-167.

Redding, Stephen J. and Rossi-Hansberg, Esteban, (2017) "Quantitative Spatial Economics" Annual Review of Economics, 9, 21-58.

Redding, S. J. and M.A. Turner (2015) 'Transportation Costs and the Spatial Organization of Economic activity' In G. Duranton, J.V. Henderson, and W. C. Strange (eds.) Handbook of Regional and Urban Economics, volume 5B. Amsterdam: Elsevier, 1339-1398.

Reed, T. and A. Trubetskoy (2019). Assessing the Value of Market Access from Belt and Road Projects Policy Research working paper; no. WPS 8815. Washington, D.C.: World Bank Group.

Roberts, Mark, Uwe Deichmann, Bernard Fingleton, and Tuo Shi (2010). On the road to prosperity? The economic geography of China's national expressway network. World Bank Policy Research Working Paper No. 5153. The World Bank, Washington, DC

Roberts, Mark, Uwe Deichmann, Bernard Fingleton, and Tuo Shi, (2012) "Evaluating China's road to prosperity: A new economic geography approach," Regional Science and Urban Economics, 42 (4), 580-594.

Rosenthal, S. and W. Strange. (2004). 'Evidence on the nature and sources of agglomeration economies'. In V. Henderson and J-F Thisse (eds.) Handbook of Regional and Urban Economics, volume 4. Amsterdam: North-Holland, 2119-2171. 


\section{Appendix 1: Cell (region/oblast) listing and data}

\section{Country}

\begin{tabular}{|c|c|}
\hline 100 & China \\
\hline 1110 & China \\
\hline 120 & China \\
\hline 100 & Kazakhstan \\
\hline 110 & Kazakhstan \\
\hline 2120 & Kazakhstan \\
\hline 2130 & Kazakhstan \\
\hline 2140 & Kazakhstan \\
\hline 2150 & Kazakhstan \\
\hline 2160 & Kazakhstan \\
\hline 2170 & Kazakhstan \\
\hline 2180 & Kazakhstan \\
\hline 2190 & Kazakhstan \\
\hline 2200 & Kazakhstan \\
\hline 2210 & Kazakhstan \\
\hline 2220 & Kazakhstan \\
\hline 2221 & Kazakhstan \\
\hline 2230 & Kazakhstan \\
\hline 2231 & Kazakhstan \\
\hline 3100 & Kyrgyzstan \\
\hline 3110 & Kyrgyzstan \\
\hline 3120 & Kyrgyzstan \\
\hline 3130 & Kyrgyzstan \\
\hline 3140 & Kyrgyzstan \\
\hline 3150 & Kyrgyzstan \\
\hline 3151 & Kyrgyzstan \\
\hline 3160 & Kyrgyzstan \\
\hline 3161 & Kyrgyzstan \\
\hline 4100 & Pakistan \\
\hline 4110 & Pakistan \\
\hline 4120 & Pakistan \\
\hline 4130 & Pakistan \\
\hline 5100 & Tajikistan \\
\hline 5110 & Tajikistan \\
\hline 5120 & Tajikistan \\
\hline 5130 & Tajikistan \\
\hline 5131 & Tajikistan \\
\hline 6100 & Turkmenistan \\
\hline 7100 & Uzbekistan \\
\hline 7110 & Uzbekistan \\
\hline 7120 & Uzbekistan \\
\hline 7130 & Uzbekistan \\
\hline 7140 & Uzbekistan \\
\hline 7150 & Uzbekistan \\
\hline 7160 & Uzbekistan \\
\hline 7170 & Uzbekistan \\
\hline 7180 & Uzbekistan \\
\hline 7190 & Uzbekistan \\
\hline 7200 & Uzbekistan \\
\hline 7210 & Uzbekistan \\
\hline
\end{tabular}

Region/oblast

City

1 Gansu

1 Qinghai

1 Xinjiang

2 Aqtobe

2 Atyrau

2 East Kazakhstan

2 Jambyl

2 Mangystau

2 North Kazakhstan

2 Pavlodar

2 Qaraghandy

2 Qostanay

2 Qyzylorda

2 South Kazakhstan

2 West Kazakhstan

2 Aqmola

2 Aqmola

2 Almaty

2 Almaty

3 Batken

3 Jalal-Abad

3 Karakol

3 Naryn

3 Talas

3 Bishkek

3 Bishkek

3 Osh

3 Osh

4 Baluchistan

4 N.W.F.P.

4 Punjab

4 Sind

5 Gorno-Badakhshan

5 Khatlon

5 Leninabad

5 Dushanbe

5 Dushanbe

6 Ashgabat

7 Andijon

Bukhoro

Ferghana

Jizzakh

7 Karakalpakstan

7 Kashkadarya

7 Khorezm

7 Namangan

7 Navoi

7 Samarkand

7 Sirdaryo

7 Surkhandarya

7 Tashkent
10 Lanzhou

11 Xining

12 Urumqi

10 Aqtobe

11 Atyrau

12 Staro-Semipalatinskiy

13 Taraz

14 Aqtau

15 Petropavlovsk

16 Pavlodar

17 Qaraghandy

18 Qostanay

19 Qyzylorda

20 Shymkent

21 Uralskiy Prigorodnyy

22 Astana_city

22 Astana

23 Almaty_city

23 Almaty

10 Batken

11 Jalal-Abad

12 Karakol

13 Naryn

14 Talas

15 Bishkek

15 Bishkek_city

16 Osh

16 Osh_city

10 Quetta

11 Peshawar

12 Lahore

13 Karachi

10 Khorugh

11 Qurghonteppa

12 Khujand

13 Dushanbe_city

13 Dushanbe

10 Ashgabat

10 Andijon

11 Buxoro

12 Fargona

13 Jizzax

14 Nukus

15 Qarshi

16 Urganch

17 Namangan

18 Navoiy

19 Samarqand

20 Bekobod

21 Termiz

22 Angren 
7230 Uzbekistan

Access points

$\begin{aligned} 8100 & \text { Chongqing } \\ 9100 & \text { Gwadar } \\ 10100 & \text { Istanbul } \\ 11100 & \text { Moscow }\end{aligned}$

7 Tashkent City

8 Chongqing

9 Gwadar

10 Istanbul

11 Moscow
23 Tashkent

10 Chonqing

10 Gwadar

10 Istanbul

10 Moscow

Employment data at this spatial level come from national sources. For China, the data for the three Western cells, Gansu, Xinjiang, and Qinghai, come from the National Bureau of Statistics in China, http://www.stats.gov.cn. For Kazakhstan, the data come from the Agency of Statistics of the Republic of Kazakhstan http://stat.gov.kz, reported at the sector and province level. In Kyrgyzstan, employment data at the region and sector level are from the National Statistical Committee of the Kyrgyz Republic http://www.stat.kg/en/. In Uzbekistan, the sector and region employment data are from the State Committee of the Republic of Uzbekistan on Statistics, https://www.stat.uz/en/. For all these countries, we select data from 2016. In Tajikistan, regional data are calculated from the Labor Force Survey 2016, Statistics Agency of Tajikistan. In Pakistan, cell and sector data are from the Labor Force Survey 20142015 available from the Pakistan Bureau of Statistics http://www.pbs.gov.pk. In Turkmenistan, data are only available at the national level, broken into sectoral employment http://www.stat.gov.tm/. We therefore only have one location within the country in our analysis.

\section{Appendix 2: The Model}

\section{Geography}

There are $n=56$ geographical cells (subscript $i, j$ from $1 \ldots n$ ), split across 52 cells in 7 countries, (subscript $c=1 \ldots 7$ ), plus an additional 4 access points for the rest of the world. Countries, cells and access points are listed in appendix 1 .

Each cell i has an area $\bar{K}_{i}$, divided into urban and rural land $\bar{K}_{i}=\bar{K}_{U i}+\bar{K}_{R i}$. It is connected to all other cells in the system, as well as the rest of the world, via a transport network. This transport network gives a transport cost matrix between every pair of cells $(n \times n)$.

The 4 access points, Moscow, Istanbul, Gwadar and Chongqing, are cities at which goods and services can be traded with the rest of the world. At these points, imports can be bought at fixed world prices, and exports can be sold according to a highly elastic rest of world demand curve discussed below.

\section{Production}

There are three productive activities: Primary good production (agriculture and mining); manufacturing and tradable services: non-tradable services, including housing and retail.

Primary Goods: Primary goods (agriculture and mining), sector s = 1, are produced using a CobbDouglas production function, using intermediates, rural land, and labor. Primary producers in cell i supply goods at price $\mathrm{p}_{1 \mathrm{i}}$ per unit with $\mathrm{c}_{1 \mathrm{i}}=\mathrm{w}_{\mathrm{i}}^{\alpha_{w 1}} r_{\mathrm{Ui}}^{\alpha_{r 1}} \mathrm{P}_{1 \mathrm{i}}{ }^{\alpha_{11}} \mathrm{P}_{2 \mathrm{i}}{ }^{\alpha_{21}} \mathrm{P}_{3 \mathrm{i}}{ }^{\alpha_{31}} / \mathrm{z}_{1 \mathrm{i}}$, where the right hand side is unit costs, with $\mathrm{w}_{\mathrm{i}}$ the wage in cell $\mathrm{i}, \mathrm{P}_{s \mathrm{i}}$ the CES price index for sector $\mathrm{s}$ in cell $\mathrm{i}, \mathrm{r}_{\mathrm{Ri}}$ the rural land rent and $\mathrm{z}_{1 \mathrm{i}}$ the cell-sector specific productivity parameter. Exponents (input shares) sum to unity, $\alpha_{w 1}+\alpha_{r 1}+\alpha_{11}+\alpha_{21}+\alpha_{31}=1$.

Demand for primary products $(s=1)$ produced in cell $\mathrm{i}$, is $\mathrm{x}_{1 \mathrm{i}}=\sum_{\mathrm{j}} \mathrm{p}_{1 \mathrm{i}}{ }^{-\sigma_{1}} A_{i j}^{1} \tau_{j i}^{1}{ }^{1-\sigma_{1}} \mathrm{E}_{1 \mathrm{j}} \mathrm{P}_{1 \mathrm{j}}{ }^{\sigma_{1}-1}$, where $\mathrm{E}_{1 j}$ is total expenditure on primary in cell $\mathrm{j}, \tau^{1}{ }_{\mathrm{ij}}$ the sector-specific bilateral iceberg trade cost, and $A_{i j}^{1}$ is a utility parameter expressing the preference for $\mathrm{i}$ 's agriculture in location $\mathrm{j}$. The CES price index is $\mathrm{P}_{1 \mathrm{i}}=\left[\sum_{\mathrm{j}} A_{j i}^{1}\left(\mathrm{p}_{1 \mathrm{j}} \tau_{j i}^{1}\right)^{1-\sigma_{1}}\right]^{1 /\left(1-\sigma_{1}\right)}$.

The value demand for each of the inputs into production can be expressed as follows:

Labor demand by sector 1 in cell $\mathrm{i}$ :

$$
\mathrm{L}_{1 \mathrm{i}}=\alpha_{w 1} \mathrm{p}_{1 \mathrm{i}} \mathrm{x}_{1 \mathrm{i}} / \mathrm{w}_{\mathrm{i}}
$$


Rural land demand by sector 1 in cell $\mathrm{i}$ :

Intermediate demand by sector s for sector 1 in cell $\mathrm{i}$ :

$$
\begin{aligned}
& \mathrm{K}_{R \mathrm{i}}=\alpha_{r 1} \mathrm{p}_{1 \mathrm{i}} \mathrm{x}_{1 \mathrm{i}} / \mathrm{r}_{R \mathrm{i}} \\
& e_{1 i}^{S}=\alpha_{s 1} \mathrm{p}_{1 \mathrm{i}} \mathrm{x}_{1 \mathrm{i}} / \mathrm{P}_{\mathrm{si}}
\end{aligned}
$$

Manufacturing and Local Services: The two other sectors, manufacturing and local services, $s=2,3$ respectively, are produced under monopolistic competition with differentiated products as modeled by Dixit-Stiglitz. ${ }^{17}$ The number of firms from sector $\mathrm{s}$ in cell $i$ is $\mathrm{n}_{s i}$. Each firm choose inputs and sales to maximize profits. Production uses labor, intermediates, and urban land. The local producer price is given by $\mathrm{c}_{s \mathrm{i}}=\mathrm{w}_{\mathrm{i}}^{\alpha_{s w}} r_{\mathrm{Ui}}^{\alpha_{s r}} \mathrm{P}_{1 \mathrm{i}}{ }^{\alpha}{ }_{1 s} \mathrm{P}_{2 \mathrm{i}}{ }^{\alpha_{2 s}} \mathrm{P}_{3 \mathrm{i}}{ }^{\alpha_{3 s}} / \mathrm{z}_{s \mathrm{i}}$ with $\alpha_{s w}+\alpha_{s r}+\alpha_{s 1}+\alpha_{s 2}+\alpha_{s 3} x=1$ for $s=2,3$. Household demand in cell $\mathrm{i}$ is $x_{s j i}^{H}=\mathrm{p}_{s \mathrm{j}}{ }^{-\sigma_{s}} A_{j i}^{S} \tau_{j i}^{s}{ }^{1-\sigma_{s}} e_{s i}^{H} \mathrm{P}_{s i}{ }^{\sigma_{s}-1}$ and the local CES price index $\mathrm{P}_{s i}=$ $\left[\sum_{j} A_{j i}^{S} \mathrm{n}_{s j}\left(\mathrm{p}_{s j} \tau_{j i}^{S}\right)^{1-\sigma_{s}}\right]^{1 /\left(1-\sigma_{s}\right)}$ At equilibrium firms make zero profits selling output quantity $\mathrm{x}_{s i}=1$. Value demands for each input are as follows:

Labor demand by sector $s=2,3$ in cell $i$ :

Urban land demand by sector $\mathrm{s}=2,3$ in cell $\mathrm{i}$ :

Intermediate demand by sector s' for sector $\mathrm{s}=2,3$ in cell $\mathrm{i}$ :

$$
\begin{aligned}
& \mathrm{L}_{s \mathrm{i}}=\alpha_{w s} \mathrm{p}_{s \mathrm{i}} \mathrm{n}_{s i} \mathrm{x}_{s \mathrm{i}} / \mathrm{w}_{\mathrm{i}} \\
& \mathrm{K}_{U s \mathrm{i}}=\alpha_{r s} \mathrm{p}_{s \mathrm{i}} \mathrm{n}_{s i} \mathrm{x}_{s i} / \mathrm{r}_{\mathrm{Ui}} \\
& e_{s i}^{s \prime}=\alpha_{s \prime s} \mathrm{p}_{s i} \mathrm{n}_{s i} \mathrm{x}_{\mathrm{si}} / \mathrm{P}_{\mathrm{ki}}
\end{aligned}
$$

$\mathrm{z}_{s \mathrm{i}}$ is the productivity of sector $s$ in cell $i$. This is composed of two elements, a base location-sectorspecific level of productivity multiplied by a scale factor. For the initial analysis, we calibrate to find $\mathrm{z}_{s \mathrm{i}}$. Further details are outlined in the simulation section below.

\section{Population}

The total population of each country is given exogenously as $\bar{L}_{c}$. For all cells $i \epsilon$ country $c$, the local population $L_{i}$ is given by the data and $\bar{L}_{c}=\sum_{i} L_{i}$. In the simulations with labor immobility each $L_{i}$ is held constant. With labor mobility $L_{i}$ can change but $\bar{L}_{c}$ is held constant. Details are outlined in the simulation section below.

Households work in their cell of residence and supply a fixed amount of labor (one household = one worker) and consume the three different goods and services. Their income in cell $\mathrm{i}$ is a combination of two components: the wage $w_{i}$, and $m_{i}$, which is a lump-sum transfer capturing the distribution of country-wide land rents and profits, assumed to be equally distributed across households in each country.

Households have Cobb-Douglas preferences over sector composite goods and indirect utility function $u_{\mathrm{i}}=\left(w_{i}+m_{i}\right) /\left(\prod_{s \in[1,3]} \mathrm{P}_{\mathrm{si}}{ }^{\beta_{s}}\right)$ with expenditure shares $\beta_{1}+\beta_{2}+\beta_{3}=1$. Total income in cell $\mathrm{i}$ is equal to $M_{i}=\left(w_{i}+m_{i}\right) L_{i}$, and total household expenditure on each sector s is therefore $e_{s i}^{H}=\beta_{s} M_{i}$.

\section{Trade}

Goods and services move between cells within and across countries consistent with each cell's supply, demand, and trade costs. Within each country, these flows are determined by the relative demand and supply of goods in each location and trade costs, $\tau^{S}{ }_{\mathrm{ij}}$.

Across country the pattern of trade is shaped also by country origin-destination preference parameters, $A_{i j}^{S}$; these take a common value $A_{c}^{S}$ for goods produced and consumed in the same country (i.e., where $\mathrm{i}, \mathrm{j}$ are in the same country $C$ ). Across international borders these preference parameters take the form: $A_{i j}^{S}=A_{C k}^{S}$, the same for all $i \in$ country $C, j \in$ country $k$. Thus, for each sector there are distinct $\mathrm{n} \times \mathrm{n}$ preference matrices, but the variation is only between countries so, if nc denotes the number of countries, $A_{i j}^{S}$ has just nc x nc distinct values. The values are found in the calibration process.

Transport times between each pair of cells allows us to estimate trade costs. We assume a relationship between the two of the form , $\tau_{i j}^{S}=1+\lambda^{s} \operatorname{time}_{i j}{ }^{\theta}$ with $\theta=0.75$ and $\lambda^{s}$ varying by industry.

\footnotetext{
${ }^{17}$ The Armington case holds the number of varieties produced in each country constant. Products are differentiated by location of production but since the number of varieties in each location is fixed, manufacturing and local services behave like agriculture.
} 
The initial international trade flows are defined by the data. In the data national trade balances are nonzero, so net imports are assumed to be paid for by net remittances from emigrants living elsewhere; the fixed base level of remittances does not change with the experiments, and neither therefore do national trade balances.

\section{Equilibrium}

Within each cell, labor, land, and all three goods/services markets must clear.

For labor in each cell i, $L_{i}=\sum_{s \in[1,3]} L_{s i}$. The total value demand in cell i for sector s output is $\mathrm{E}_{s i}=$ $e_{s i}^{1}+e_{s i}^{2}+e_{s i}^{3}+e_{s i}^{H}$, which must equal the value produced in the cell net of any exports out of the cell and imports into the cell. Land market clearing within each cell is given by $\bar{K}_{R i}=K_{1 i}, \bar{K}_{U i}=K_{U i}=$ $\sum_{s \in[2,3]} K_{U s i}$ and $\bar{K}_{i}=\bar{K}_{U i}+\bar{K}_{R i}$. Together these market clearing conditions determine $\mathrm{r}_{\mathrm{Ri}}, \mathrm{r}_{\mathrm{Ui}}, \mathrm{w}_{\mathrm{i}}, \mathrm{P}_{1 \mathrm{i}}, \mathrm{P}_{2 \mathrm{i}}$, and $\mathrm{P}_{3 \mathrm{i}}$.

Lump sum transfer payments, $m_{i}$, are determined through splitting total land rents nationwide equally among all the population within the country, regardless of where they live, such that, for cells $i \epsilon$ country $c, m_{i}=\sum_{i \in c}\left(\bar{K}_{U i} \mathrm{r}_{\mathrm{Ui}}+\bar{K}_{R i} \mathrm{r}_{\mathrm{Ri}}\right) / \bar{L}_{c}$.

\section{Calibration}

The model's equilibrium is calibrated to the base data set by choice of productivity parameters, $z_{s i}$, and country origin-destination shift parameters, $A_{i j}^{S}$. The $z_{s i}$ are calibrated to match observed employment levels in each sector-cell and per capita income levels across countries. $A_{i j}^{S}$ are calibrated to match the international trade data.

The calibration proceeds in three main steps. First, we calibrate relative $z_{s i}$ within each country, so that equilibrium employment in each sector and cell matches the employment data. Second, the absolute levels of $z_{s i}$ in each country are scaled to match income per capita at a country level. Finally, we calibrate preference parameters $A_{i j}^{S}$ such that the share of country $i$ output being sold in country $j$ is consistent with international trade data.

\section{Simulations}

The calibrated model is 'shocked' with new transport time matrices, and firms and households adjust their decisions to optimally respond to the new connectivity of the region. We look at four different levels of economic response

(1) The direct trade value of the transport cost reduction. We take the base value of exports of each cell according to the destination and calculate the reduction in costs in shipping the same amount of goods and services that results from the decreased travel times. No demand or supply response occurs.

(2) Armington assumption; the number of firms/ varieties of products produced in each cell is held constant. Output per firm adjusts, as do equilibrium prices and demands.

(3) Monopolistic competition in manufacturing production, where the number of firms in each cell in sectors 2 and 3 adjusts in response to profit opportunities until equilibrium is restored

(4) Monopolistic competition with increasing returns to scale in manufacturing (localization economies) and some intra-country labor mobility.

In setting (4), under increasing returns, $z_{s i}$, the calibrated productivity of sector $s$ in cell $i$ is composed of two elements. First, a base productivity of sector-cell, $\bar{z}_{s i}$, and second, an additional component which represents potential increasing returns to as a function of the density of firms in the sector-cell (denoted by $\bar{n}_{s i}$ ) and taking the form $z_{s i}=\bar{z}_{s i}\left(1+\alpha\left(n_{s i} / \bar{L}_{i}\right)\right)^{\rho}$. The density of firms in expressed as a density per population in the cell in the base period, capturing the effective size of the space in which the firm is located.

If, following the transport investment, the number of firms increases (or decreases), then returns to scale change productivity, where $\rho>0$ if there are increasing returns. We assume that $\rho>0$ only in setting (4) and in sector 2. Parameters $\alpha$ and $\rho$ are chosen such that areas with average firm density are $20 \%$ 
more productive than comparable areas with no firms, and that the cell will the mean value $n_{s i} / \bar{L}_{i}$ has an elasticity of productivity with respect to the number of firms equal to 0.08 , these two restrictions implying parameter values $\alpha=6.67$ and $\rho=0.093$. This translates into a point elasticity of productivity with respect to the number of firms that ranges from 0 in cells with no initial manufacturing to a maximum of 0.088 .

Labor mobility is captured by assuming that $L_{i}=\bar{L}_{i} u_{i}{ }^{\mu} /\left(\sum_{j \in c} L_{j} u_{j}{ }^{\mu} / \sum_{j \in c} L_{j}\right)$, where $\bar{L}_{i}$ is the base exogenous population in the cell pre any scenario, coming directly from the data. $\mu=0$ implies labor is completely immobile within the country, as in settings (1) to (3). $\mu=\infty$ would imply perfect labor mobility. The total national population must equal the sum of all cell populations within the country $\bar{L}_{c}=\sum_{i \in c} L_{i}$. Results with labor mobility are computed with $\mu=10$.

In settings (2) - (4), the amount of urban land is able to adjust in response to changes in the urban-rural rent differential, so that $K_{U i}=\bar{K}_{U i}\left(\left(\mathrm{r}_{\mathrm{Ui}} / \bar{r}_{\mathrm{Ui}}\right) /\left(\mathrm{r}_{\mathrm{Ri}} / \bar{r}_{\mathrm{Ri}}\right)\right)^{\nu}$. We set $v=0.5$.

\section{Appendix 3}

Employment: Employment data were gathered on a country by country level, and national sources are described in appendix 1.

Population: Population data are from the Gridded Population of the World v4. GPWv4 depicts the distribution of human population across the globe. Source data are provided in 30 arc-second $(\sim 1 \mathrm{~km})$ grid cells (CIESIN 2016).

Land area: Land areas are extracted from European Space Agency data, with land types reported in $300 \mathrm{~m}$ square pixels. These are aggregated into our land areas. Rural land is defined as irrigated and rain-fed land, and mosaic cropland. Urban land includes all built areas (Defourny 2017).

National Accounts: National Accounts data on Gross Value Added by sector are from United Nations accounts data for $2016 \mathrm{http}$ ://data.un.org. Total populations and GDP are given below in Table 1 . There is large variation between the countries in the region, with per capita GDP nearly 10 times as large in Kazakhstan as it is in Tajikistan. The share of each sector in GVA is shown in Table 2 below. China-3 and Kazakhstan have the highest share of GVA in manufacturing, while primary sectors are relatively important in Turkmenistan and Tajikistan.

Trade: Trade values are reported on a country-to-country basis, using value data from the BACI database of CEPII, 2016, www.cepii.fr (Gaulier and Zignago 2010). These data are split by sector into agricultural and mining trade (primary production) and manufacturing and services trade. For the countries we consider, the trade data report the value of total trade in business services to be just $1.4 \%$ of the value of total trade in manufacturing, and we combine this sector with manufacturing. Over $95 \%$ of the services in our employment data are local services (housing, local utilities, retail etc.), and these constitute our non-tradable service sector. The total value of trade - exports in particular - is relatively small compared to GDP, and notably so for some of the smaller countries in the region (Table 3). There are also large imbalances in terms of the trade levels, with the three Chinese regions and Kazakhstan having trade surpluses, and other countries having deficits (explained through the presence of large remittances and other transfers). Kyrgyzstan's imports amount to more than $70 \%$ of its GDP.

\section{Appendix 4: Parameters}

The assumed parameters in the model are listed in the table below. Each sector of production employs intermediates, land, and labor. Primary good production relies on rural land, whereas manufacturing and non-tradeable services rely on urban land (the latter has the highest value share of land in production, as this sector includes real estate and therefore all housing production). Primary good production is the most labor intensive of sectors/

Transport costs are calculated using a linear relationship from the transport time (in days) $\tau_{j i}^{S}=1+$ $\lambda^{s}$ time $_{i j}{ }^{\theta}$, as in Alder (2017), Roberts et al., (2012), Baum-Snow et al. (2018). Costs are highest from 
non-tradeable services which are produced and sold predominantly in the same location, and lowest for manufacturing, for which longer travel times do not lead to much loss in terms of the value of the good. $\theta$ is chosen at 0.75 , reflecting similar assumptions elsewhere in the literature such as for rural goods in China in Roberts et al. (2012). There are other ways of modeling the impacts of transport times on transport costs, such as through an exponential model in Lall and Lebrand (2019).

The GVA data from the UN National Accounts, and the consequent Gross Output values calculated from input-output matrices, combined with the net trade flows from each country, gives a total value of output of each sector consumed within each country. From these, national consumption value shares for each sector, $\beta_{1}, \beta_{2}, \beta_{3}$, are calculated.

Parameters

\begin{tabular}{|c|c|c|c|}
\hline & $\begin{array}{l}\text { Primary } \\
\text { Goods, } s=1\end{array}$ & $\begin{array}{l}\text { Manufacturing, } \\
s=2\end{array}$ & $\begin{array}{l}\text { Non-Tradeable } \\
\text { Services, } s=3\end{array}$ \\
\hline \multicolumn{4}{|l|}{ Input of good or factor $\backslash$ to sector $\mathrm{s}$} \\
\hline \multirow{5}{*}{$\begin{array}{l}\text { Primary Goods } \alpha_{1 s} \\
\text { Manufacturing } \alpha_{2 s} \\
\text { Non-Tradable Services } \alpha_{3 s} \\
\text { Land } \alpha_{r s} \\
\text { Labour } \alpha_{w s}\end{array}$} & 0 & 0.2 & 0.1 \\
\hline & 0.1 & 0.2 & 0.1 \\
\hline & 0.1 & 0.1 & 0.1 \\
\hline & Rural 0.25 & Urban 0.1 & Urban 0.3 \\
\hline & 0.55 & 0.4 & 0.4 \\
\hline \multicolumn{4}{|l|}{ Transport Costs } \\
\hline$\lambda^{s}$ & 0.18 & 0.09 & 1.8 \\
\hline$\theta$ & 0.75 & 0.75 & 0.75 \\
\hline \multicolumn{4}{|l|}{ Elasticities } \\
\hline \multirow{2}{*}{$\begin{array}{l}\text { CES consumption } \sigma_{s} \\
\text { Export demand } \eta_{s}\end{array}$} & 6 & 6 & 6 \\
\hline & 10 & 10 & 10 \\
\hline Returns to scale, $\alpha, \rho$ & 0 & $\alpha=6.67, \rho=0.093$. & 0 \\
\hline \multicolumn{2}{|c|}{ Mobility; $\mu=0$ (immobile) or 10 (mobile) } & \multicolumn{2}{|c|}{ Urban Land Supply elasticity, $v=0.5$} \\
\hline
\end{tabular}

